Article

\title{
Characterization of a New Bifunctional and Cold-Adapted Polysaccharide Lyase (PL) Family 7 Alginate Lyase from Flavobacterium sp.
}

\author{
Hai-Xiang Zhou ${ }^{1, \dagger}$, Shan-Shan $\mathrm{Xu}^{2,+}$, Xue-Jing Yin ${ }^{3}$, Feng-Long Wang ${ }^{1, *}$ and Yang Li ${ }^{4, *}$ \\ 1 Tobacco Research Institute, Chinese Academy of Agricultural Sciences, Qingdao 266101, China; \\ pro.zhouhaixiang@163.com \\ 2 College of Life Sciences and Oceanography, Shenzhen University, Shenzhen 518060, China; \\ xushanshan328@163.com \\ 3 Qingdao Mental Health Center, Qingdao University, Qingdao 266034, China; yinxuejing@163.com \\ 4 School of Biology and Biological Engineering, South China University of Technology, \\ Guangzhou 510006, China \\ * Correspondence: wangfenglong@caas.cn (F.-L.W.); liyang881219@126.com (Y.L.) \\ + These authors contributed equally to this work.
}

Received: 10 July 2020; Accepted: 24 July 2020; Published: 26 July 2020

check for updates

\begin{abstract}
Alginate oligosaccharides produced by enzymatic degradation show versatile physiological functions and biological activities. In this study, a new alginate lyase encoding gene alySO2 from Flavobacterium sp. S02 was recombinantly expressed at a high level in Yarrowia lipolytica, with the highest extracellular activity in the supernatant reaching $36.8 \pm 2.1 \mathrm{U} / \mathrm{mL}$. AlyS02 was classified in the polysaccharide lyase (PL) family 7 . The optimal reaction temperature and $\mathrm{pH}$ of this enzyme were $30^{\circ} \mathrm{C}$ and 7.6, respectively, indicating that AlyS02 is a cold-adapted enzyme. Interestingly, AlyS02 contained more than $90 \%$ enzyme activity at $25^{\circ} \mathrm{C}$, higher than other cold-adapted enzymes. Moreover, AlyS02 is a bifunctional alginate lyase that degrades both polyG and polyM, producing diand trisaccharides from alginate. These findings suggest that AlySO2 would be a potent tool for the industrial applications.
\end{abstract}

Keywords: alginate lyase; bifunctional; cold-adapted; Flavobacterium sp. S02; Yarrowia lipolytica

\section{Introduction}

Over the past decades, development and application of algal biomass have been increasingly emphasized in various fields [1-3]. As the major ingredient in the cell wall and intracellular matrix, alginate is the largest amount of polysaccharide in brown algae, accounting for as much as $40 \%$ of the dry weight [4]. Hence, it has become essential source of raw material nowadays. Alginate is a linear hetero-polysaccharide composed of $\beta$-D-mannuronate $(\mathrm{M})$ and $\alpha$-L-guluronate $(\mathrm{G})$ units, which are linked by 1, 4-o-glycoside bonds and arranged into three kinds of block structures: polyM block, polyG block and alternating or random MG block (polyMG) [5]. Alginate has been used as a food additive thanks to its gelling property, high viscosity and chemical stability [6]. Besides, it has many other applications in pharmaceutical and food industries, chemical processes and biotechnology research [7-10]. Alginate oligosaccharides, the depolymerization products of alginate by enzymatic catalysis, have attracted more attention due to their better solubility and remarkable biological activities compared with macromolecular alginates [11]. They can be used as therapeutic agents such as anticoagulants, tumor inhibitors, anti-allergy medicine, and anti-viral drugs [12-15]. They also possess other diverse physiological functions that are beneficial to humans, e.g., antioxidation, regulating immune functions, and proliferating bifidobacteria [16-19]. In addition, alginate oligosaccharides 
can be used to stimulate protection against pathogens and as growth promoters for plants [20-22]. Therefore, the production of alginate oligosaccharides is extremely important for various fields.

Alginate lyase belongs to polysaccharide lyase (PL) family that cleaves the 1, 4-o-glycosidic bonds of alginate through $\beta$-elimination mechanism, thus creating a saturated uronate at the new reducing terminus and an unsaturated 4-deoxy-L-erythro-hex-4-enopyranosyluronic acid $(\Delta)$ with a double bond between C-4 and C-5 at the new non-reducing terminus [23]. Based on the action mode on substrates, alginate lyases are generally divided into endolytic and exolytic types [24]. Most alginate lyases exhibit endolytic activity that cleave internal glycosidic linkages of the alginate chain to release a mixture of unsaturated oligosaccharides with different degrees of polymerization (DPs) as major products [25-29]. However, there are also a few exo-type alginate lyases (EC 4.2.2.26), also known as oligoalginate lyases, which cut the glycoside bond at the end of the alginate polymer, generating products with homogeneous DP [30,31]. Moreover, endo-alginate lyases can be further classified into two groups in terms of the substrate specificities, i.e., polyguluronate-specific lyase (polyG lyase, EC4.2.2.11) which prefer catalyzing the degradation of polyG to polyM [32,33], and polymannuronate-specific lyase (polyM lyase, EC4.2.2.3) that display higher activities toward polyM [34,35]. But some enzymes manifest high activities against both polyG and polyM, called bifunctional alginate lysaes, which may degrade alginate more effectively [36-38]. Additionally, there still exist a special group among all the alginate lysaes that prefer breaking up MG-blocks to homogenous substrates, namely polyMG-specific lyases [39]. According to the Carbohydrate-Active Enzyme (CAZy) databases (http://www.cazy.org/fam/acc_PL.html), the reported alginate lyases have been organized into PL5, 6, 7, 14, 15, 17, and 18 families on the basis of their primary structures, whereas most of the enzymes belong to the PL7 family [40,41]. So far, alginate lyases, especially endo-type enzymes, have been not only applied in the preparation of alginate oligosaccharides [11,42,43], but also for biotechnology research (e.g., elucidation of alginate structures, preparation of protoplast) [44,45], disease treatment (e.g., therapy of cystic fibrosis, inhibition of pathogen bacteria) [46,47], and marine environmental protection (e.g., disposal of seaweed wastes) [48]. As a result, it is of great urgency to discover novel alginate lyases with excellent characteristics (i.e., high activity, high stability and broad substrate specificity).

Alginate lyases mainly distribute in diverse marine-derived organisms including microbes [33,49-51], mollusks [52], algae [53], and some Chlorella viruses [54]. In the past several years, many alginate lyases with various properties have been isolated, cloned, purified and characterized from those sources especially from a diversity of marine bacteria [55]. However, few of these reported enzymes have been commercially used owing to their poor properties [56]. Several alginate lyases with certain specific characteristics have been found and studied, such as pH stability [51,57], thermo-tolerance [58], cold adaption [59,60], acidic or alkaline adaption [61,62], single product distribution $[63,64]$, which are quite significant for both research and commercial purposes, but the enzymes with optimal characteristics are rare. It is worth noting that cold-adapted alginate lyases make running biocatalysis at low temperature possible, which is crucial to reduce the danger of contamination and improve the sustainability of enzyme utilization, thereby decreasing the input costs to some extent, particularly for industrial production of oligosaccharides.

In this study, a novel bifunctional and cold-adapted PL family 7 alginate lyase AlyS02 with considerable properties was purified and characterized in detail, after the encoding gene was identified in a marine-originated bacterium Flavobacterium sp. S02 and expressed using Yarrowia lipolytica. The AlyS02 degraded alginate, producing di- and trisaccharides as major products. These special features suggest that AlyS02 would be a useful enzyme for industrial applications.

\section{Results and Discussions}

\subsection{Sequence Analysis of AlySO2}

The bacterium Flavobacterium sp. S02 was isolated from brown seaweed in the Yellow Sea, China, the genomic analysis of which implied there existed a putative alginate lyase-encoding gene alyS02 
(Genbank number MT338519), with 921 bp of open reading frame (ORF). Thus, the translated AlyS02 consisted of 306 amino acid residues with a putative signal peptide ( $\mathrm{Met}^{1}$ to $\mathrm{Thr}^{22}$ ) in its N-terminal predicted by signal peptide analysis (Figure 1). Furthermore, the molecular weight $(\mathrm{Mw})$ and $\mathrm{pI}$ value of the mature enzyme were calculated as $32.79 \mathrm{kDa}$ and 9.11, respectively. According to the analysis of the InterProScan application, a single-domain $\left(\mathrm{Ile}^{55}-\mathrm{His}^{306}\right.$ ) that belongs to alginate lyase superfamily 2 was identified in the novel alginate lyase AlyS02 (Figure 1).

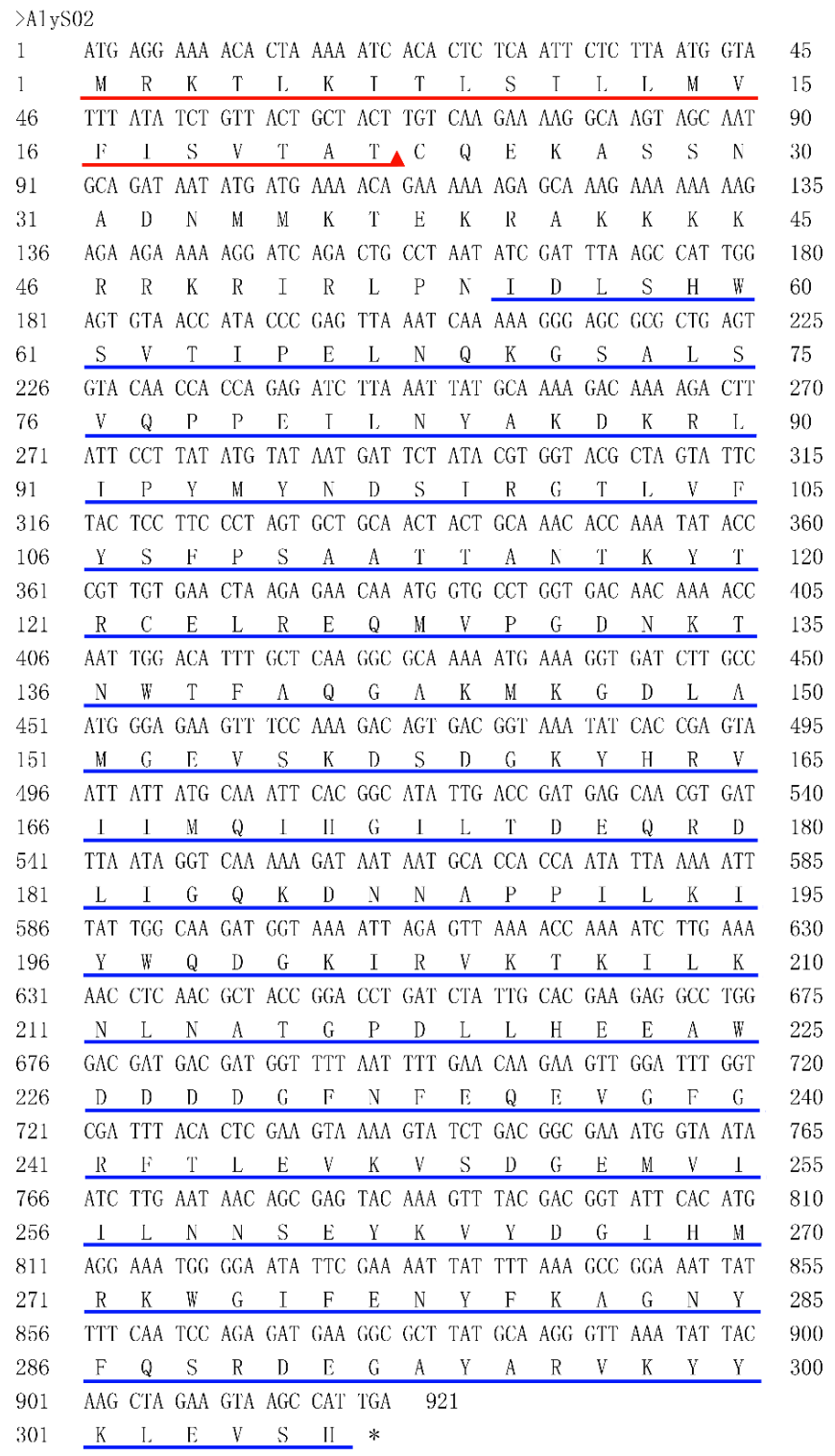

Figure 1. Nucleotide and its deduced amino acid sequences of alginate lyase gene alySO2. The ORF (open reading frame) was composed of $921 \mathrm{bp}$ and encoded AlyS02 containing 306 amino acids with a putative signal peptide marked with a red line, and the predicted cleavage site between TAT-CQ. The alginate_lyase2 domain is underlined with a blue line.

On the basis of the sequences of AlyS02 and some other alginate lyases reported from different families, a phylogenetic tree was created through the Neighborhood-joining method (Figure 2), indicating that AlyS02 belonged to PL family 7. Moreover, the alginate lyases from that family can be grouped into several subfamilies. As displayed in Figure 2, AlyS02 (Genbank number MT338519) was at the same deeply branched cluster with Alg2A (Genbank number AEB69783) and FlAlyA (Genbank number BAP05660), demonstrating that AlyS02 was a member of subfamily 6. 


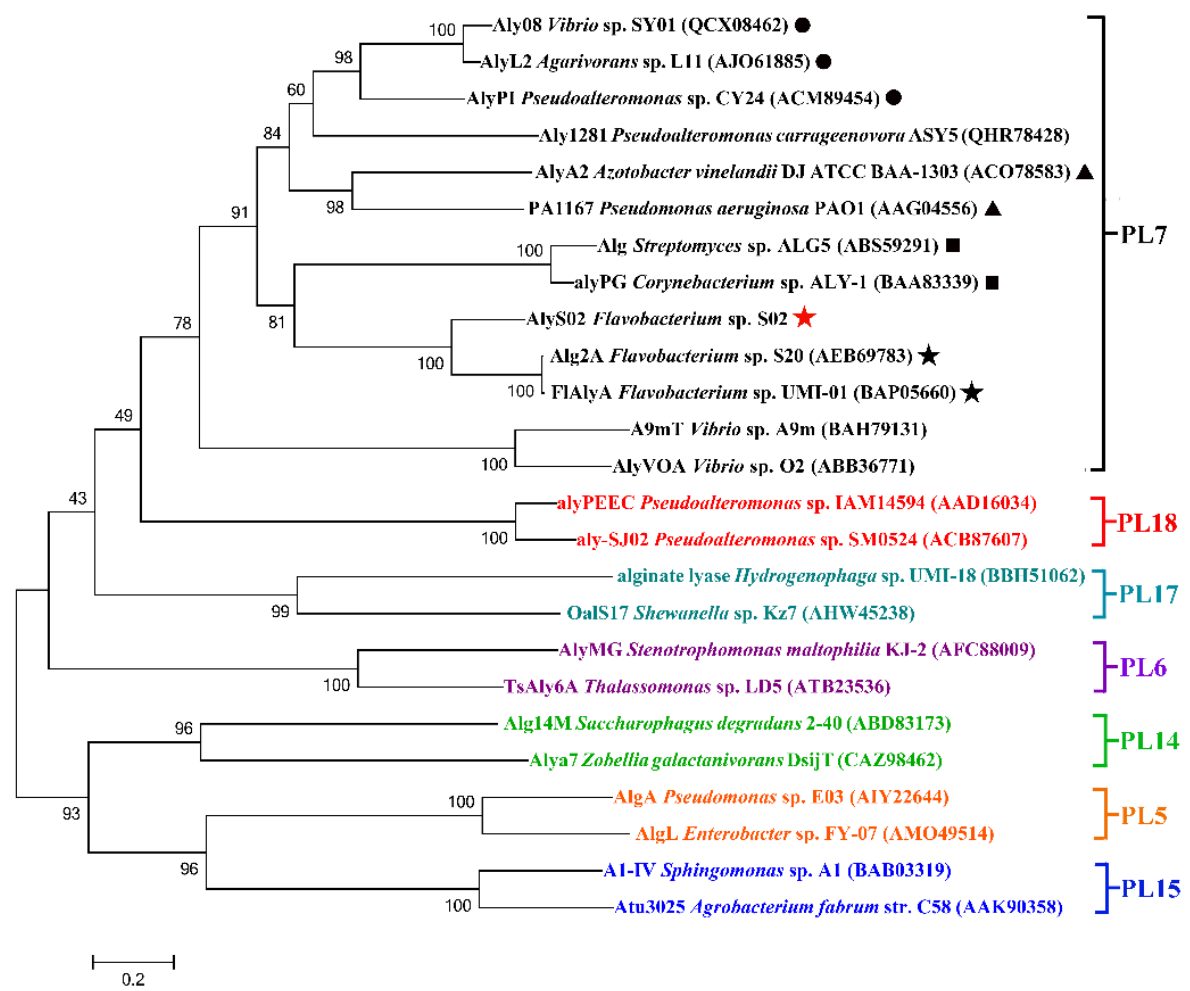

Figure 2. The phylogenetic analysis of AlyS02 and related alginate lyases. Bar, 0.2 substitutions per nucleotide position. The red five-pointed star indicates AlyS02 in this study. Different families are shown in different colors. In the PL7 family, black triangles, solid circles, boxes and five-pointed stars indicate subfamily 1 , subfamily 3 , subfamily 5 and subfamily 6 , respectively.

Among all the reported alginate lyases, AlyS02 was most closely related to alginate lyase FlAlyA (GenBank number BAP05660) from Flavobacterium sp. UMI-01 and Alg2A (GenBank number AEB69783) from Flavobacterium sp. S20 with the sequence identities of both $56.31 \%$. The alignment of the alginate_lyase2 domains among AlyS02 and several previously characterized alginate lyases from PL7 are shown in Figure 3, indicating that AlyS02 contained 3 highly conserved regions of RXELR, Q(I/V)H and YFKAGXYXQ, which were responsible for binding and catalyzing the substrate in PL7 family. It has been reported that QIH and QVH are related to substrate recognition, the former recognizes polyG and polyMG [61], such as Alg2A from Flavobacterium sp. S20 (Figure 3), and the latter prefers polyM [65], implying that AlyS02 may be polyG-preferred. Moreover, catalytic sites (Q169, H171, and Y285) were predicted in AlyS02 based on previous research on alginate lyase AlyA5 from Zobellia galactanivorans DsijT and Aly1281 from Pseudoalteromonas carrageenovora ASY5 [64,66]. The results of sequence alignment further confirmed that AlyS02 belongs to the PL7 family. 


\begin{tabular}{|c|c|c|}
\hline AlyS02 & IDISHWSVT IFELN . QRKGSASVQPPE ILNYAKDKRLIPYMYNDSIRGT & 48 \\
\hline Alg2A & IDWSHWTVTVEEENPDKPGKPYSLGYPEILNYAEDKIASKYMYDLPKDKS & 50 \\
\hline FlAlyA & IDWSHWTVTVEEENPDKPGKPYSLGYPE ILNYAEDKIASKYMYDDPKDKS & 50 \\
\hline A1-II' & FDISHWKLQIEDAN.TTEISSANLG . . . . . LGYTSCYFYTDTDG.A & 39 \\
\hline PA1167 & .DISTWNLT IEQGRPAITISTSQLQ $\ldots \ldots \ldots$ RLYRSDYFQRTADG . . & 38 \\
\hline $\mathrm{A} 9 \mathrm{mT}$ & . .SELQISDEAGR . . . KGNRLYIA . . . . TNTDFSGVVNEVFYVDKDTEA & 40 \\
\hline AlyVOA & SELCISDENGK . . . KGNKEYFG . . . . LDNDFTGIVNDNFYVDKCSCA & 40 \\
\hline Consensus & $\overrightarrow{\mathrm{p}}$ & \\
\hline AlySY02 & QELRECMVPGDNKTNWTFACGAKMKGDLAMG & 98 \\
\hline $\mathrm{Alg} 2 \mathrm{~A}$ & VVEYAFPSGVTTANTHYSRSELRETMETGSNKVNWTFAKGGKMRGTYAID & 100 \\
\hline FlAlyA & VVFYAF PSGVTTANTHYSRSELRETMETGSNKVNWTFAKGGKMRGTYAID & 100 \\
\hline A1-II' & MTFWAPTTGGTTANSSYARSELREMLDPSNSKVNWGWQGTHTMKLSGKTV & 89 \\
\hline PA1167 & IR FWVPVNGSHTRNSEF FRSELRETLSSGRPYNWRYARADNWLEATLRIE & 88 \\
\hline $\mathrm{A} 9 \mathrm{mT}$ & ..... DHKRNELRVHKNFNTSLPHTFYHLNASIEPVNPEA & 82 \\
\hline Aly $\mathrm{VOA}$ & .... DHLBNELRVQRNERTDLPDHFYTLNANVE IMHPQQ & 82 \\
\hline Consensus & $\begin{aligned} & r \text { elr } \\
+ & \Delta\end{aligned}$ & \\
\hline AlySY02 & EVSKDSDGKYHRVIIM CIHGILTDEQRDL IGQRDNNAEEILKIYWQDGKI & 148 \\
\hline $\mathrm{Alg} 2 \mathrm{~A}$ & DISKEPLGKYSRVIIZ IHGVLTDEQRDL IGCKDNNAEFILKVYWDKGKI & 150 \\
\hline FlAlyA & DISKEPDGKYSRVIIZ IHGVLTDEQRDL IGCKDNNAEFILKVYWDKGKI & 150 \\
\hline A1-II' & QLPSSGK . . . IIVZ & 125 \\
\hline PA1167 & AVPSTRR . . . MIIG IHSDGSNSGQ .........ARELVKLLYQLLRLD & 124 \\
\hline $\mathrm{A} 9 \mathrm{mT}$ & SMRDSTS.RQNEITYI QVHNKGVTVDG.... KDNIPHFLLRVVWREGAG & 126 \\
\hline Aly YOA & SMTNSTS.RQNEITFIQVHNKGLDLLG. . . . THNVPHELLRVVWKEDNQ & 126 \\
\hline Consensus & $\mathrm{q} \mathrm{h}$ & \\
\hline AlySY02 & RVKTKILKNLNATGPDLLHEEAWDLDLGFNFEQEVGFG.RFTLEVKVSD. & 196 \\
\hline $\mathrm{Alg} 2 \mathrm{~A}$ & RVKTKVLKDLNAPYKEMLLEHAWGDDEGRNFREKIDLNTRETLEVKVSD. & 199 \\
\hline FlAlyA & RVKTKVLKDLNAPYKEMLSEHAWGDDEGRNFKEKIDLNTRETLEVKVSD. & 199 \\
\hline A1-II' & DMQVRQNSDGTG $\ldots \ldots \ldots \ldots$ SDVHNYFTGIKLGDLYNMEIRVTLG & 162 \\
\hline PA1167 & QGRVQALVREREDD $\ldots \ldots \ldots$ GGTRAYTLMDGIPLGQPFSYRIGVSR. & 164 \\
\hline $\mathrm{A} 9 \mathrm{mT}$ & ETAGHYWAVIKDNALICKGKKGKENIGKPACKSENAYK. QYLLGKAKTG. & 174 \\
\hline \multirow{2}{*}{$\begin{array}{l}\text { AlyvoA } \\
\text { Consensus }\end{array}$} & GVRGHFWAITKNNAVICKGSFGKKNKDKEMCRADVAYS.KIDLGPAPTDK & 175 \\
\hline & $x^{2}+y^{2}$ & \\
\hline AlySY02 & 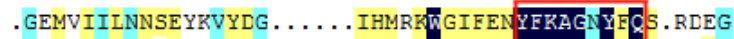 & 238 \\
\hline $\mathrm{Alg} 2 \mathrm{~A}$ & .GRMEVILNDTESLVYDD. . . . . IHMKKRGIFENYFRAGNYEQS.KTPG & 241 \\
\hline FlAlyA & .GRMEVILNDTESLVYDD. . . . . IHMKKRGIFENYFRAGNYEQS.KTPG & 241 \\
\hline $\mathrm{A} 1-\mathrm{II}$ & .VAYVTMNGDTRSVDFVG . . . . . KDAGRKNLKYYFRAGNYVDNTSTG & 204 \\
\hline PA1167 & SGLLSVSVNGSALEQQLD $\ldots \ldots \ldots$ PQWAYQGIYFRAGIYIQDNRGPS & 205 \\
\hline $\mathrm{A} 9 \mathrm{mT}$ & ATDFNIIVGNSTLIVNVDGRQRVNHNIDYRSHLISYFKAGVYNQE.TNGE & 223 \\
\hline Aly VOA & GTDFTITVGNKTLSIDVNGQRMVERDIDYRRHLLSYFKAGVYNQE .TNGE & 224 \\
\hline Consensus & yfkag y q & \\
\hline AlySY02 & AY.ARVRYYKLEVS & 251 \\
\hline $\mathrm{Alg} 2 \mathrm{~A}$ & TF.AKVRIYSLQVT & 254 \\
\hline FlAlyA & TE.AKVKIYSLCVT & 254 \\
\hline A1-II' & GS.AIARLYSLSVS & 217 \\
\hline PA1167 & SEGGRATFSELRVS & 219 \\
\hline $\mathrm{A} 9 \mathrm{mT}$ & SE.ARFYQLEYQVE & 236 \\
\hline AlyVOA & SE.AHFTELSY... & 234 \\
\hline
\end{tabular}

Figure 3. Multiple sequence alignment of A1yS02. AlyS02 from Flavobacterium sp. S02 in this study, Alg2A (AEB69783) from Flavobacterium sp. S20, FlAlyA (BAP05660) from Flavobacterium sp. UMI-01, A1-II' (BAD16656) from Sphingomonas sp. A1, PA1167 (AAG04556) from Pseudomonas aeruginosa PAO1, A9mT (BAH79131) from Vibrio sp. JAM-A9m, AlyVOA (ABB36771) from Vibrio sp. O2. The conserved regions are highlighted with red boxes. Red triangles indicate the potential residues involved in the catalytic activity in the PL7 family.

\subsection{Expression and Purification of Recombinant AlySO2}

The vector pINA1312-alyS02 was successfully constructed in Escherichia coli DH5 $\alpha$ and transformed into Y. lipolytica after linearization. The transformant $\mathrm{Y} 32$ possessed the highest extracellular activity $(36.8 \pm 2.1 \mathrm{U} / \mathrm{mL})$. After $72 \mathrm{~h}$ cultivation at $30{ }^{\circ} \mathrm{C}$ in GPPB medium, the recombinant AlyS02 was purified using Ni-NTA Sepharose affinity chromatography, eventually reaching 442.84 U/mg (Table 1). The specific activity of recombinant AlyS02 was subject to a slight decrease after the second ultrafiltration step, which might be caused by the immense pressure coming from the collisions between protein molecules and ultrafiltration membrane during the high-speed centrifugation. In this work, engineering strain Y. lipolytica $\mathrm{URA}^{-}$was used to express the recombinant AlyS02 rather than other commercial stains such as E. coli BL21 or Pichia pastoris X33, firstly because of the insecurity of the strains above 
(e.g., methanol used as inducer for P. pastoris) [67], whereas the yeast Y. lipolytica has been identified by FDA as GRAS (generally regarded as safe). Not only that, due to the remarkable capability of post-translational processing and secreting proteins, Y. lipolytica is recognized as a favorable choice for heterologous protein expression [68].

Table 1. Summary of the purification of AlyS02.

\begin{tabular}{cccccc}
\hline Purification Step & Total Protein $(\mathbf{m g})$ & Total Activity (U) & Specific Activity (U/mg) & Purification Fold & Yield (\%) \\
\hline Crude enzyme & 43.14 & 3680 & 85.3 & 1 & 100 \\
Ultrafiltration 1st & 38.32 & 3520.5 & 91.87 & 1.08 & 95.67 \\
Ni-NTA sepharose & 4.86 & 2217.9 & 456.36 & 5.35 & 60.27 \\
Ultrafiltration 2nd & 4.72 & 2090.2 & 442.84 & 5.19 & 56.8 \\
\hline
\end{tabular}

The recombinant AlyS02 was further analyzed by SDS-PAGE, and the result is shown in Figure 4. There was a single band of recombinant Alys02 located at the gel with an Mw of approximate $36.5 \mathrm{kDa}$, suitable for downstream biochemical characterization. The Mw of AlyS02 was slightly higher than the theoretical value probably due to the recombinant AlySY02 fused with $6 \times \mathrm{His}-\mathrm{tag}$, whose molecular mass would be larger with 312 amino acids. Moreover, recombinant AlyS02 might be glycosylated during expression and secretion proceeds by yeast [67]. The enzymes from diverse microorganisms differ in size, ranging from 23 to $110 \mathrm{kDa}$ [11]. Depending on molecular masses, the alginate lyases have been classified into three groups: large ( $>60 \mathrm{kDa}$ ), medium (more or less $40 \mathrm{kDa}$ ) and small (25-30 kDa) [11,36]. Therefore, AlyS02 in this research belongs to the small-sized alginate lyases. The alginate lyases Cel32 from Cellulophaga sp. NJ-1 [11], alySJ-02 from Pseudoalteromonas sp. SM0524 [36], A1m from Agarivorans sp. JAM-A1m [62], and the alginate lyase from Pseudoalteromonas sp. strain No. 272 [69], have molecular masses of $32 \mathrm{kDa}, 32 \mathrm{kDa}, 31 \mathrm{kDa}$ and $33.9 \mathrm{kDa}$, respectively, similar to the Mw of AlyS02.

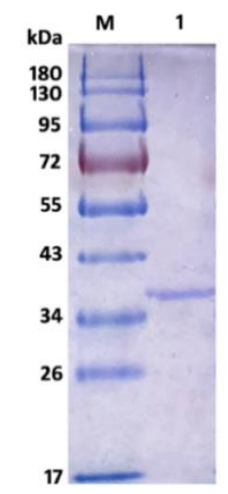

Figure 4. SDS-PAGE of purified AlyS02. Lane M, protein marker; lane 1, purified AlyS02.

\subsection{Characterization of Recombinant AlySO2}

The recombinant AlyS02 presented the optimal temperature of $30^{\circ} \mathrm{C}$ and contained more than $70 \%$ of relative activity in the range of $20-40{ }^{\circ} \mathrm{C}$ (Figure $5 \mathrm{~A}$ ). Compared with other enzymes, AlyS02 had a wider temperature range for the activity. However, the activity of AlyS02 significantly reduced when the temperature exceeded $40{ }^{\circ} \mathrm{C}$ (Figure 5A). These results demonstrated that AlyS02 was a cold-adapted enzyme. Similar to AlyS02, the optimum temperatures of most cold-adapted alginate lyases reported are $30-35{ }^{\circ} \mathrm{C}$, as displayed in Table 2. However, AlyS02 still possessed more than $90 \%$ of maximum activity at $25^{\circ} \mathrm{C}$, higher than other cold-adapted enzymes at the same condition, such as AlyPM from Pseudoalteromonas sp. SM0524 and TsAly6A from Thalassomonas sp. LD5 [59,60], meaning that AlyS02 could be used at room temperature which is convenient and conducive to cost reduction. AlyS02 remained around 80\% activity after incubation for $2 \mathrm{~h}$ at $30{ }^{\circ} \mathrm{C}$, and with favorable thermostability at the temperature below $30^{\circ} \mathrm{C}$ (Figure 5B). Combined with relatively 
high activity at room temperature, AlyS02 was able to degrade the alginate completely, releasing oligosaccharides before its inactivation. However, the thermostability of AlyS02 declined significantly when the temperature came to be higher than $30^{\circ} \mathrm{C}$, signifying it should be stored for a long time at a lower temperature. A considerable advantage of expression proteins in eukaryotic cells is that diverse modifications could be introduced during post-translational processing, among which the glycosylation has been found with the function to enhance the thermostability of proteins [70]. Thus, the approach of improvement of the stability of the enzymes by adding extra $\mathrm{N}$-glycosylation sites in the protein molecules via site-directed mutagenesis was advisable [71]. Enzyme immobilization is another effective means to further stabilize enzymes. Kunjukunju et al. prepared a cross-linked aggregate of alginate lyase that was thermally stable up to $50^{\circ} \mathrm{C}$ over a period of $8 \mathrm{~h}$, and compared with the native enzyme the reusability and storage stability were both improved [72]. The favorable methods described above would be used in the future for stabilizing alginate lyases, especially cold-adapted ones such as AlyS02.
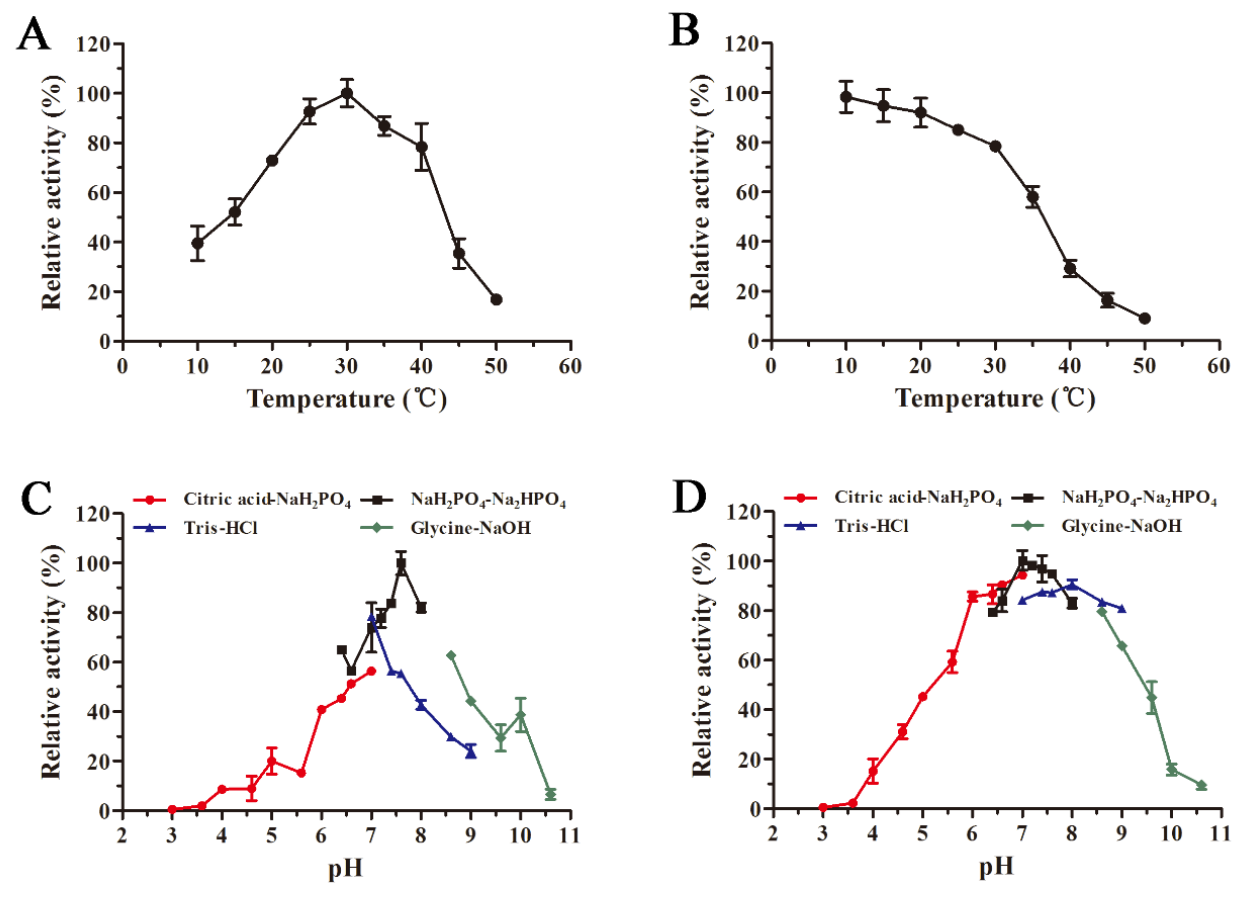

Figure 5. Influences of temperature and $\mathrm{pH}$ on the activity and stability of AlyS02. (A) Optimal temperature of AlyS02. The enzyme activities were measured at different temperatures $\left(10-50{ }^{\circ} \mathrm{C}\right)$ and the relative activities were calculated by setting the activity at the optimum temperature as $100 \%$. (B) Thermal stability of AlyS02. The residual activities were tested after incubation for $2 \mathrm{~h}$ at different temperatures $\left(10-50{ }^{\circ} \mathrm{C}\right.$ ) and calculated by using the initial activity as $100 \%$. (C) Optimal pH of AlyS02. The enzyme activities were determined with the citric acid- $\mathrm{NaH}_{2} \mathrm{PO}_{4}$ buffer $(\mathrm{pH} 3.0-7.0)$, $\mathrm{NaH}_{2} \mathrm{PO}_{4}-\mathrm{Na}_{2} \mathrm{HPO}_{4}$ buffer ( $\mathrm{pH}$ 6.4-8.0), Tris- $\mathrm{HCl}$ buffer ( $\mathrm{pH}$ 7.0-9.0), and Glycine-NaOH buffer ( $\mathrm{pH}$ 8.6-10.6), and the relative enzyme activities were calculated by taking the activity at optimal $\mathrm{pH}$ as $100 \%$. (D) pH stability of AlyS02. The residual activities were detected after AlyS02 was incubated for $24 \mathrm{~h}$ at $4{ }^{\circ} \mathrm{C}$ in the $\mathrm{pH} 3.0-10.6$ in the buffers above, and the maximum residual activity was considered as $100 \%$. Relative activity is expressed as a percentage and the data represented as the mean \pm standard deviation of triplicate measurements. 
Table 2. Comparison of the properties of AlyS02 with the related alginate lyases from various microorganisms.

\begin{tabular}{|c|c|c|c|c|c|c|c|c|c|}
\hline Enzyme Name & Organism/Source & PL Family & $\mathrm{Mw}(\mathrm{kDa})$ & Optimal pH/Temperature $\left({ }^{\circ} \mathrm{C}\right)$ & Cation Activators & Cation Inhibitors & $\begin{array}{l}\text { Substrate } \\
\text { Specificity }\end{array}$ & $\begin{array}{c}\text { Main } \\
\text { Products (DP) }\end{array}$ & References \\
\hline AlyS02 & $\begin{array}{l}\text { Flavobacterium sp. S02/Y. } \\
\text { lipolytica }\end{array}$ & 7 & 36.5 & $7.6 / 30$ & $\mathrm{Na}^{+}, \mathrm{K}^{+}, \mathrm{Ca}^{2+}, \mathrm{Mg}^{2+}$ & $\begin{array}{c}\mathrm{Fe}^{3+}, \mathrm{Al}^{3+}, \mathrm{Mn}^{2+}, \mathrm{Cu}^{2+}, \mathrm{Zn}^{2+}, \mathrm{NH}_{4}^{+}, \\
\mathrm{Li}^{+}, \mathrm{SDS}, \mathrm{EDTA}\end{array}$ & PolyG, polyM & 2,3 & This study \\
\hline $\mathrm{Alg} 2 \mathrm{~A}$ & Flavobacterium sp. S20/E. coli & 7 & 33 & $8.5 / 45$ & $\mathrm{Na}^{+}, \mathrm{K}^{+}$ & $\begin{array}{c}\mathrm{Ca}^{2+}, \mathrm{Mg}^{2+}, \mathrm{Co}^{2+}, \mathrm{Cu}^{2+}, \mathrm{Zn}^{2+}, \mathrm{Mn}^{2+}, \\
\mathrm{Fe}^{2+}\end{array}$ & PolyG & $5-7$ & [32] \\
\hline FlAlyA & $\begin{array}{l}\text { Flavabacterium sp. } \\
\text { UMI-01/native }\end{array}$ & 7 & 30 & $7.7 / 55$ & $\mathrm{Na}^{+}, \mathrm{K}^{+}, \mathrm{Ca}^{2+}, \mathrm{Mg}^{2+}$ & $\mathrm{Co}^{2+}, \mathrm{Ni}^{2+}$ & $\begin{array}{l}\text { PolyM, } \\
\text { polyMG }\end{array}$ & $2-5$ & [26] \\
\hline PA1167 & P. aeruginosa PAO1/E. coli & 7 & 25 & $8.5 / 40$ & N.D. & N. D. & PolyMG & $2-4$ & [39] \\
\hline Aly1281 & P. carrageenovora ASY5/E. coli & 7 & 40.65 & $8.0 / 50$ & $\mathrm{Na}^{+}, \mathrm{K}^{+}$ & N. D. & PolyG, polyM & 2 & [64] \\
\hline AlgNJ-04 & Vibrio sp. NJ-04/E. coli & 7 & 50.19 & $7.0 / 40$ & $\mathrm{Na}^{+}, \mathrm{K}+\mathrm{Ca}^{2+}$ & $\mathrm{Fe}^{2+}, \mathrm{Cu}^{2+}, \mathrm{Zn}^{2+}$ & PolyG, polyM & $2-5$ & [51] \\
\hline $\mathrm{A} 9 \mathrm{mT}$ & Vibrio sp. JAM-A9m/E. coli & 7 & 28 & $7.5 / 30$ & $\begin{array}{c}\mathrm{Na}^{+}, \mathrm{K}^{+}, \mathrm{Li}^{+}, \mathrm{Rb}^{+}, \mathrm{Cs}^{+}, \\
\mathrm{NH}_{4}^{+} \text {, Tween } 20, \text { Nonidet } \mathrm{P} 40\end{array}$ & $\mathrm{Cu}^{2+}, \mathrm{Zn}^{2+}, \mathrm{Ni}^{2+}, \mathrm{Co}^{2+}, \mathrm{Sr}^{2+}, \mathrm{SDS}$ & PolyM & N.D. & [74] \\
\hline Algb & Vibrio sp. W13/E. coli & 7 & 54.12 & $8.0 / 30$ & $\mathrm{Na}^{+}, \mathrm{Ca}^{2+}, \mathrm{Co}^{2+}, \mathrm{Fe}^{2+}$ & $\mathrm{Cu}^{2+}, \mathrm{Zn}^{2+}, \mathrm{Mn}^{2+}, \mathrm{Ba}^{2+}$ & $\begin{array}{c}\text { PolyMG, } \\
\text { polyG, polyM }\end{array}$ & $2-5$ & [25] \\
\hline Aly08 & Vibrio sp. SY01/E. coli & 7 & 35 & $8.35 / 45$ & $\mathrm{Na}^{+}, \mathrm{Ca}^{2+}, \mathrm{Mn}^{2+}, \mathrm{Co}^{2+}, \mathrm{Zn}^{2+}$ & SDS, EDTA & PolyG & 2,3 & [61] \\
\hline Aly510-64 & Vibrio sp. 510-64/native & N.D. & 34.6 & $7.5 / 35$ & $\mathrm{Na}^{+}, \mathrm{K}^{+}, \mathrm{Ca}^{2+}, \mathrm{Mg}^{2+}, \mathrm{Li}^{+}$ & N. D. & $\begin{array}{l}\text { PolyG, } \\
\text { polyMG }\end{array}$ & 3 & [63] \\
\hline AlySY08 & Vibrio sp. SY08/native & N.D. & 33 & $7.6 / 40$ & $\mathrm{Na}^{+}, \mathrm{K}^{+}, \mathrm{Ca}^{2+}, \mathrm{Mg}^{2+}$ & $\begin{array}{l}\mathrm{Fe}^{3+}, \mathrm{Al}^{3+}, \mathrm{Mn}^{2+}, \mathrm{Cu}^{2+}, \mathrm{Zn}^{2+}, \mathrm{SDS}, \\
\mathrm{EDTA}, 2 \text {-mercaptoethanol }\end{array}$ & PolyG, polyM & 2 & [29] \\
\hline AlgA & Bacillus sp. Alg07/native & N.D. & 60 & $7.5 / 40$ & $\begin{array}{c}\mathrm{Na}^{+}, \mathrm{Ca}^{2+}, \mathrm{Mn}^{2+}, \mathrm{Mg}^{2+}, \\
\mathrm{Co}^{2+}\end{array}$ & $\begin{array}{c}\mathrm{Fe}^{3+}, \mathrm{Fe}^{2+}, \mathrm{Cu}^{2+}, \mathrm{Al}^{3+}, \mathrm{Hg}^{2+}, \mathrm{Ba}^{2+}, \\
\text { EDTA }\end{array}$ & PolyM & $2-4$ & [35] \\
\hline Cel32 & Cellulophaga sp. NJ-1/native & N. D. & 32 & $8.0 / 50$ & $\mathrm{Na}^{+}, \mathrm{K}^{+}, \mathrm{Ca}^{2+}, \mathrm{Mg}^{2+}$ & $\mathrm{Fe}^{2+}, \mathrm{Cu}^{2+}, \mathrm{Zn}^{2+}, \mathrm{Co}^{2+}, \mathrm{Ni}^{2+}$ & $\begin{array}{c}\text { PolyMG, } \\
\text { polyG, polyM }\end{array}$ & 2,3 & [11] \\
\hline rSAGL & $\begin{array}{l}\text { Flavobacterium sp. } \mathrm{H} 63 / P . \\
\text { pastoris }\end{array}$ & 7 & 32 & $7.5 / 45$ & $\mathrm{Na}^{+}, \mathrm{K}^{+}, \mathrm{Mg}^{2+}$ & $\begin{array}{c}\mathrm{Co}^{2+}, \mathrm{Cu}^{2+}, \mathrm{Zn}^{2+}, \mathrm{Mn}^{2+}, \mathrm{Ca}^{2+}, \mathrm{Ni}^{2+}, \\
\mathrm{Fe}^{3+}, \mathrm{Ag}^{+}\end{array}$ & PolyM & $2-4$ & [67] \\
\hline rAlgSV1-PL7 & Shewanella sp. YH1/E. coli & 7 & 33.216 & $8.0 / 45$ & $\mathrm{Na}^{+}, \mathrm{K}^{+}, \mathrm{Mg}^{2+}$ & $\mathrm{Cu}^{2+}, \mathrm{Fe}^{3+}, \mathrm{N}$-bromosuccinimide & $\begin{array}{l}\text { PolyG, polyM, } \\
\text { polyMG }\end{array}$ & $1-4$ & [27] \\
\hline Aly2 & Flammeovirga sp. MY04/E. coli & 7 & 60.58 & $6.0 / 40$ & $\begin{array}{c}\text { EDTA, glycerol, } \\
\text { 2-mercaptoethanol }\end{array}$ & $\begin{array}{c}\mathrm{Ag}^{+}, \mathrm{Hg}^{2+}, \mathrm{Pb}^{2+}, \mathrm{Fe}^{3+}, \mathrm{Zn}^{2+}, \mathrm{Ni}^{2+}, \mathrm{Fe}^{2+} \\
\mathrm{Cu}^{2+}, \mathrm{Cr}^{3+}, \mathrm{K}^{+}, \mathrm{Mn}^{2+}, \mathrm{SDS}^{2}\end{array}$ & PolyG, polyM & 2,3 & [73] \\
\hline TsAly6A & Thalassomonas sp. LD5/E. coli & 6 & 83.9 & $8.0 / 35$ & $\mathrm{Ca}^{2+}, \mathrm{Mg}^{2+}, \mathrm{Na}^{+}$ & EDTA, SDS & PolyG, polyM & 2,3 & [60] \\
\hline aly-SJ02 & $\begin{array}{l}\text { Pseudoalteromonas sp. } \\
\text { SM0524/native }\end{array}$ & 18 & 32 & $8.5 / 50$ & $\begin{array}{c}\mathrm{Na}^{+}, \mathrm{K}^{+}, \mathrm{Ba}^{2+}, \mathrm{Ca}^{2+}, \mathrm{Mg}^{2+}, \\
\mathrm{Mn}^{2+}, \mathrm{Co}^{2+}, \mathrm{Sr}^{2+}, \mathrm{Ni}^{2+}\end{array}$ & EDTA & PolyG, polyM & $2-4$ & [36] \\
\hline A1-IV' & Sphingomonas sp. A1/E. coli & 15 & 90 & $8.5 / 50$ & N. D. & $\mathrm{Cu}^{2+}, \mathrm{Zn}^{2+}, \mathrm{Hg}^{2+}, \mathrm{Co}^{2+}$ & $\begin{array}{l}\text { PolyM, } \\
\text { polyMG }\end{array}$ & 2,3 & [50] \\
\hline $\operatorname{Alg} A$ & Pseudomonas sp. E03/E. coli & 5 & 40.4 & $8.0 / 30$ & $\begin{array}{l}\mathrm{Na}^{+}, \mathrm{K}^{+}, \mathrm{Ca}^{2+}, \mathrm{Mg}^{2+}, \mathrm{Zn}^{2+}, \\
\mathrm{Ba}^{2+}, \mathrm{PMSF}, \mathrm{DTT}\end{array}$ & $\begin{array}{l}\mathrm{Co}^{2+}, \mathrm{Cu}^{2+}, \mathrm{Mn}^{2+}, \mathrm{Fe}^{2+}, \text { Triton } \mathrm{X}-100, \\
\text { Tween 20, EDTA, SDS, urea }\end{array}$ & PolyM & $2-5$ & [34] \\
\hline
\end{tabular}


The optimal $\mathrm{pH}$ of recombinant AlyS02 was determined as 7.6 and it maintained over $60 \%$ of relative activity at $\mathrm{pH}$ ranging from 6.4 to 8.6 (Figure 5C). AlyS02 was mostly stable at pH 7.0 and had a favorable stability at a broad $\mathrm{pH}$ range of $6-9$, with over $80 \%$ activity retained after being incubated for $24 \mathrm{~h}$ (Figure 5D). Therefore, AlyS02 was an alkaline-stable enzyme. Generally, the alginate lyases from PL7 family preferred neutral or slightly alkaline conditions. As shown in Table 2, pH 7-8.5 is the generally optimal $\mathrm{pH}$ characteristic of the alginate lyases from the PL7 family, except Aly2 from Flammeovirga sp. MY04, whose optimal pH was 6.0 [73]. Surprisingly, under the same $\mathrm{pH}$ conditions, the enzyme activity with Tris- $\mathrm{HCl}$ buffer was significantly lower than that in phosphate buffer (Figure 5C), which has been reported before [27,69]. The possible reasons for this phenomenon are that AlySO2 was activated by $\mathrm{Na}^{+}$and Tris would destroy the enzyme more or less.

The influence of $\mathrm{NaCl}$ concentration on AlyS02 activity is revealed in Figure 6A. AlyS02 was activated within 100-900 $\mathrm{mM}$ of $\mathrm{NaCl}$, and the activity reached the maximum with $500 \mathrm{mM} \mathrm{NaCl}$, approximately $250 \%$ of relative activity compared to that without $\mathrm{NaCl}$ (Figure 6A). The results indicated that AlyS02 was a salt-activated and salt-tolerant alginate lyase, but not dependent on $\mathrm{Na}^{+}$. This phenomenon also partially explained the influences of various buffer solutions in the tests of $\mathrm{pH}$ characteristics. The salt-activated property was common in the enzymes isolated from marine bacteria (Table 2), where the survival of these strains and activation of the enzymes need the environment to have a certain degree of $\mathrm{NaCl}$ concentration. The effects of various metals $(1 \mathrm{mM})$ on AlyS02 activity were also examined. As exhibited in Figure 6B, the enzyme activity was increased with $\mathrm{Mg}^{2+}, \mathrm{Ca}^{2+}$, and $\mathrm{K}^{+}$, just as most alginate lyases listed in Table 2 . However, the enzyme activity was prominently reduced with SDS, EDTA, $\mathrm{Cu}^{2+}$ and $\mathrm{Zn}^{2+}$, and partially decreased with other metal ions such as $\mathrm{NH}_{4}^{+}$, $\mathrm{Li}^{+}, \mathrm{Mn}^{2+}, \mathrm{Al}^{3+}$ and $\mathrm{Fe}^{3+}$. Similar situations could be found in many alginate lyases originated from marine environments; most trivalent and divalent heavy metal ions and other reagents such as SDS and EDTA can significantly inhibit the activities of the enzymes, perhaps owing to the denaturation of enzymes (Table 2). However, some exceptional cases exist in previous studies. Interestingly, SDS could activate AlyYKW-34 from Vibrio sp. YKW-34 [75]. The activity of Aly2 from Flammeovirga sp. MY04 would be enhanced in the presence of EDTA [73], and $\mathrm{Ba}^{2+}$ and $\mathrm{Co}^{2+}$ showed obviously activating effects on aly-SJ02 from Pseudoalteromonas sp. SM0524 [36]. The influences of ions on the enzymes derived from diverse species may be different due to the various environments for diverse bacteria strains to survive and evolve [25].
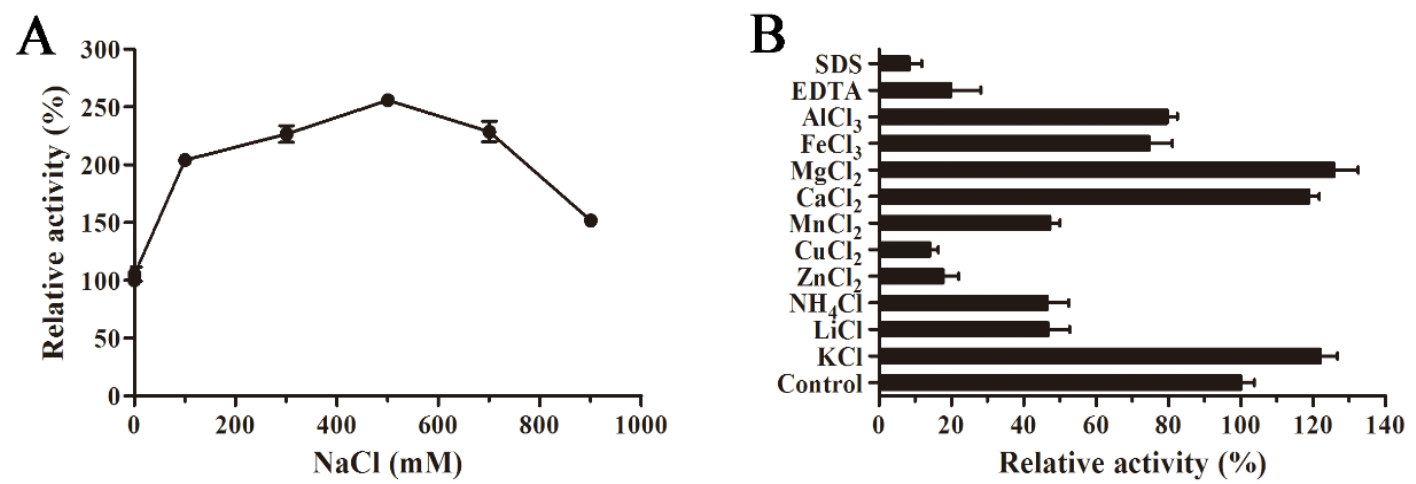

Figure 6. Influences of $\mathrm{NaCl}$, various metal ions and chemical compounds on AlyS02 activity. (A) Effect of $\mathrm{NaCl}$ on AlyS02. The activity of the control was relatively taken as $100 \%$. (B) Effect of different metal ions, EDTA and SDS on AlyS02. Each value represents the mean of three replicates \pm standard deviation.

\subsection{Substrate Specificity and Degradation Pattern of AlySO2}

To investigate the substrate specificity of AlyS02, three kinds of polymeric substrates (polyG, polyM and sodium alginate) were utilized. The relative catalytic activities of AlyS02 against tested substrates are shown in Figure 7. The result indicated that this enzyme is a bifunctional alginate 
lyase which degrades both polyM and polyG (Figure 7). Most alginate lyases are specific to M block or G block, called monofunctional enzymes [33,35,61,74]. The utilization of those enzymes was limited except for some particular purpose such as preparation of polyM block from alginate through degrading the polyG and polyMG blocks [76]. However, AlyS02 with broader substrate specificity was capable of degrading alginate more effectively, similar to other bifunctional alginate lyases reported $[11,19,29,36,37]$. The $\mathrm{Q}(\mathrm{I} / \mathrm{V}) \mathrm{H}$ conserved sequences important for substrate recognition and catalysis exist in almost all the alginate lyases from PL7 family [25,55]. In the current study, AlyS02 was found to degrade polyG more efficiently than the other assayed polymeric substrates (Figure 7); this result corresponded with the QIH sequence in the primary structure of AlyS02 described previously. Nevertheless, there still are some exceptions to this rule. Yagi et al. reported that rAlgSV1-PL7 with QVH was highly active against polyG [27]. The polyM-preferred FlAlyA contains QIH in the amino acid sequence [26].

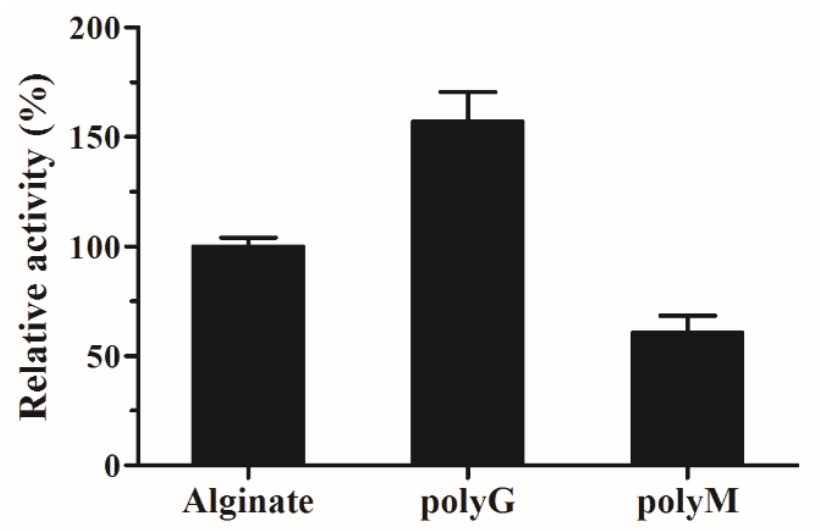

Figure 7. Substrate specificity of AlyS02. Substrates were alginate, poly G and polyM.

In order to further determine the pattern of AlyS02 action towards sodium alginate, thin layer chromatography (TLC), size exclusion chromatography (SEC) and electrospray ionization mass spectrometry (ESI-MS) methods were used to analyze the degradation products (Figure 8). The process of catalyzed breakdown was analyzed firstly by TLC assay at different time intervals. As shown in Figure 8A, with gradual reduction of alginate polysaccharides, the oligosaccharides with low DPs appeared and accumulated as the proceeding of enzymatic reaction. After incubation for $30 \mathrm{~min}$, two clear spots whose migration rates were in line with the alginate disaccharide (DP2) and trisaccharide (DP3) marker on the TLC plate manifested that the hydrolysis pattern of AlyS02 was endo-type.

Furthermore, the distribution of final depolymerization products was monitored by SEC using high performance liquid chromatography (HPLC) platform, and dimers and trimers were proved to be the major products (Figure 8B). The result of ESI-MS is displayed in Figure 8C and DPs with the corresponding mass-to-charge ratios $(\mathrm{m} / \mathrm{z})$ of unsaturated oligosaccharides are shown in Table 3 . Under the negative mode, DPs of the end product were implied to be $2(351.0 \mathrm{~m} / \mathrm{z})$ and $3(526.9 \mathrm{~m} / \mathrm{z})$ owing to the predominant ion peaks of $[\Delta \mathrm{DPx}-\mathrm{H}]^{-}(\mathrm{x}=2,3)[19,42]$. There were also some weak peaks consistent with DP 2, 3 of the products (Figure $8 \mathrm{C}$ and Table 3). It is necessary to mention that the ion peak with $174.9 \mathrm{~m} / \mathrm{z}$ represented disaccharides from $[\Delta \mathrm{DP} 2-2 \mathrm{H}]^{2-}$ species rather than monosaccharides [29], owing to no monosaccharide was detected using TLC and SEC methods, which differ from the earlier researches of rAlgSV1-PL7 and Aly08 [27,61]. 

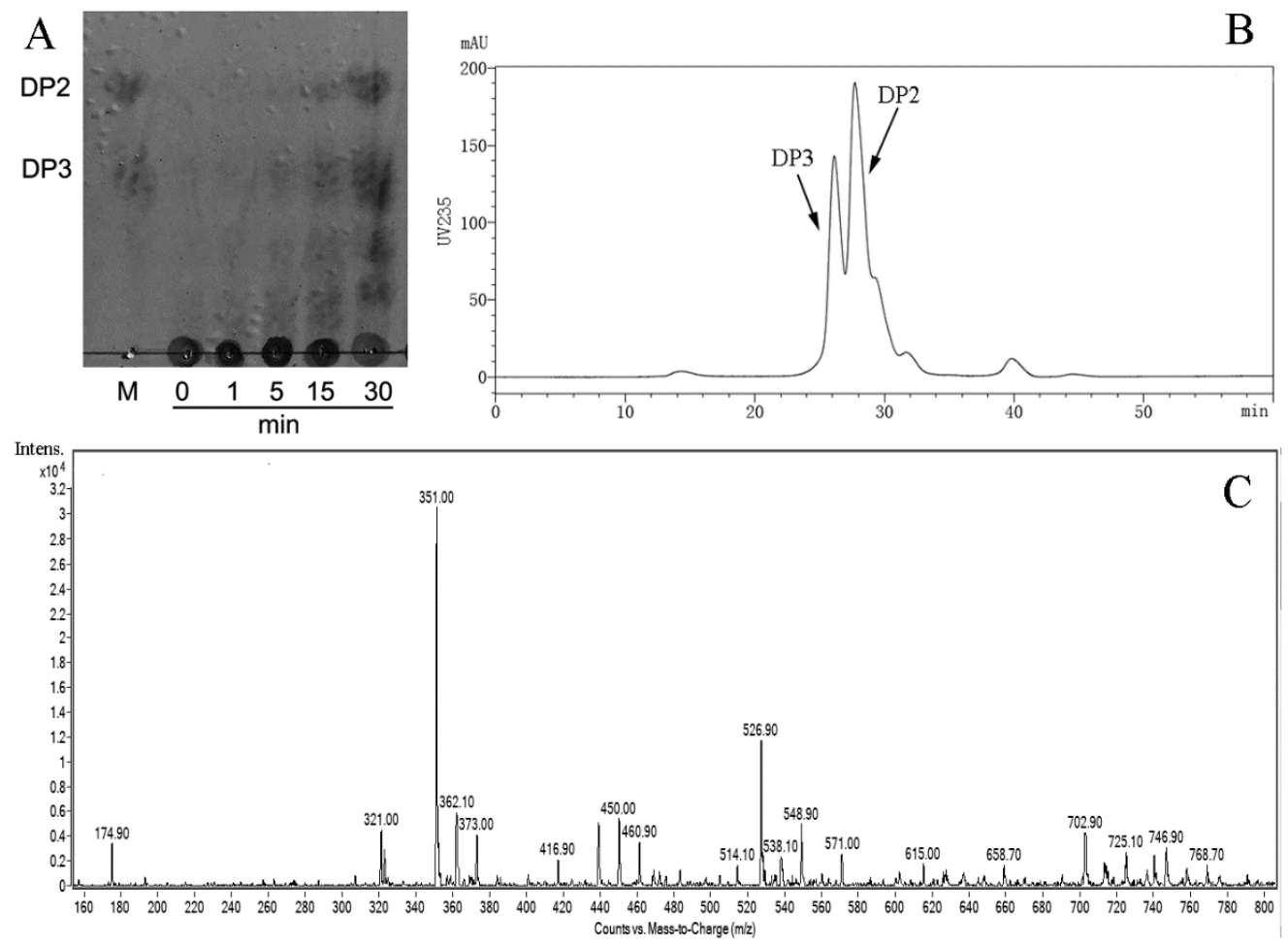

Figure 8. The products generated by AlyS02-degrading alginate were analyzed by TLC (thin layer chromatography), SEC (size exclusion chromatography) and ESI-MS (electrospray ionization mass spectrometry). (A) TLC analysis of the depolymerization products of AlyS02 toward alginate for 0, 1, 5, 15 and $30 \mathrm{~min}$. DP2 indicates dimer, DP3 indicates trimer. (B) SEC analysis of the degradation products of AlyS02 toward alginate. (C) ESI-MS analysis of the degradation products of AlyS02 against alginate.

Table 3. ESI-MS analysis for the DPs (degrees of polymerization) of alginate oligomers.

\begin{tabular}{ll}
\hline Ion Mode & $m / z$ \\
\hline$[\Delta \mathrm{DP} 2-\mathrm{H}]-$ & 351 \\
{$[\Delta \mathrm{DP} 2-2 \mathrm{H}] 2-$} & 175 \\
{$[\Delta \mathrm{DP} 2-2 \mathrm{H}+\mathrm{Na}]-$} & 373 \\
{$[\Delta \mathrm{DP} 3-\mathrm{H}]-$} & 527 \\
{$[\Delta \mathrm{DP} 3-2 \mathrm{H}+\mathrm{Na}]-$} & 549 \\
{$[\Delta \mathrm{DP} 3-3 \mathrm{H}+2 \mathrm{Na}]-$} & 571 \\
\hline
\end{tabular}

All the results illustrated that AlyS02 depolymerized alginate polymers in an endolytic manner into unsaturated disaccharides and trisaccharides eventually, between which the former accounted for a larger fraction. The findings were similar to other endo-alginate lyases from PL7 family in Table 2, which released the oligosaccharides of DP 2, 3 as main products too [11,61,73]. Although alginate lyases with a variety of action modes degrade alginate to produce oligosaccharides with different DPs, such as 2-4 [36,39], 2-5 [26,33] and 3, 4 [77], DP values of catalyzed products do not exceed 2-5 in most cases [40]. However, alginate lyases with special action patterns have also been discovered. Alg2A from Flavobacterium sp. S20 appears to take penta-, hexa- and hepta-alginate oligosaccharides as the major depolymerization products [32]. Some alginate lyases can cleave the substrate mainly releasing the products with single DP distribution [63,64]. During the enzymatic preparation of oligosaccharides, high degradation specificity will be conducive for the oligosaccharide purification and application. The end products of AlyS02 are di- and trisaccharides, which are propitious to further separation and industrial high-efficiency production. 
Currently, the biological activities and physiological functions of oligosaccharides derived from enzymatic degradation of alginate are being studied. Unsaturated mannuronate and guluronate oligomers (M3-M6 and G3-G6) can induce the secretion of a variety of cytokines, e.g., monocyte chemoattractant protein-1 (MCP-1), granulocyte colony-stimulating factor (G-CSF) and tumor necrosis factor- $\alpha(\mathrm{TNF} \alpha)$ in the mouse macrophage cell line RAW264.7 [14]. Pentamers contained antitumor activity aimed at osteosarcoma cells, which results from their antioxidant and anti-inflammatory activities [78]. Alginate oligosaccharides with DP 2-4 taking guluronic acid at the reducing terminus showed the effective stimulation to the proliferation and migration of human endothelial cells [79]. Moreover, alginate oligosaccharides with DP 3-6 could promote root growth of lettuce seedlings [80]. The bifunctional AlyS02 has potential to be a potent tool for the effective generation of highly specific unsaturated oligosaccharides which have fascinated researchers due to wide food and pharmaceutical applications.

\section{Materials and Methods}

\subsection{Materials, Strains and Culture Conditions}

Sodium alginate $(\mathrm{M} / \mathrm{G}$ ratio: 1.66; viscosity: $500 \mathrm{cP})$ from Macrocystis pyrifera was purchased from Qingdao Bright Moon Seaweed Group Co., Ltd. (Qingdao, China). D-polymannuronic acid (PolyM; M/G ratio 97.3/2.7, purity: 99\%) and L-polyguluronic acid (polyG; M/G ratio 1.8/98.2, purity: $99 \%$ ) were bought from Qingdao BZ Oligo Biotech Co., Ltd. (Qingdao, China). Standard alginate disaccharide and trisaccharide were also purchased from Qingdao BZ Oligo Biotech Co., Ltd.

Marine-derived bacterium Flavobacterium sp. S02 was isolated from brown seaweed in the Yellow Sea, China. E. coli $\mathrm{DH} 5 \alpha$ was used for plasmid construction and amplification, cultured in Luria-Bertani (LB) medium with appropriate antibiotics $\left(100 \mu \mathrm{g} / \mathrm{mL}\right.$ ampicillin or $50 \mu \mathrm{g} / \mathrm{mL}$ kanamycin) at $37^{\circ} \mathrm{C}$. The uracil mutant strain Y. lipolytica $\mathrm{URA}^{-}$and pINA1312 vector used for alyS02 gene expression were provided by Prof. Zhenming Chi, Ocean University of China. The recombinant strains of Y. lipolytica were screened on a YNB plate, containing $10.0 \mathrm{~g} / \mathrm{L}$ glucose, $1.7 \mathrm{~g} / \mathrm{L}$ yeast nitrogen base, $5.0 \mathrm{~g} / \mathrm{L}\left(\mathrm{NH}_{4}\right)_{2} \mathrm{SO}_{4}$ and $20.0 \mathrm{~g} / \mathrm{L}$ agar [81]. The GPPB liquid medium was applied for recombinant alginate lyase production by the transformant obtained, containing $30.0 \mathrm{~g} / \mathrm{L}$ glucose, $2.0 \mathrm{~g} / \mathrm{L}$ yeast extract, $1.0 \mathrm{~g} / \mathrm{L}\left(\mathrm{NH}_{4}\right)_{2} \mathrm{SO}_{4}, 3.0 \mathrm{~g} / \mathrm{L} \mathrm{K}_{2} \mathrm{HPO}_{4}, 2.0 \mathrm{~g} / \mathrm{L} \mathrm{KH}_{2} \mathrm{PO}_{4}, 0.1 \mathrm{~g} / \mathrm{L} \mathrm{MgSO} 4 \cdot 7 \mathrm{H}_{2} \mathrm{O}, \mathrm{pH} 6.8$ [81].

\subsection{Sequence Analysis of AlySO2}

In previous work, the marine bacterium Flavobacterium sp. S02 displayed the ability to degrade alginate and grow in an alginate sole-carbon medium (data not shown). The genomic sequence analysis of Flavobacterium sp. S02 implied that there was a putative alginate lyase-encoding gene, named alySO2 and deposited in Genbank database (Genbank number MT338519). The ORF was recognized by ORF finder (https://www.ncbi.nlm.nih.gov/orffinder/). The signal peptide cleavage site of AlyS02 was predicted through the SignalP 5.0 server (http://www.cbs.dtu.dk/services/SignalP/). The conserved domain of AlyS02 and its family were analyzed using the InterProScan application (http://www.ebi.ac.uk/interpro/search/sequence/). The theoretical pI and Mw of AlyS02 were calculated with the compute $\mathrm{pI} / \mathrm{Mw}$ Tool (https://web.expasy.org/compute_pi/).

The bootstrapped phylogenetic tree was constructed via MEGA 6.0 by the neighbor-joining method [82], based on the amino acid sequences of related alginate lyases acquired from NCBI (https://www.ncbi.nlm.nih.gov/). The alignment of amino acid sequences was carried out using DNAMAN 6.0 (Lynnon Biosoft, USA).

\subsection{Secretory Expression and Purification of Recombinant AlySO2}

To express AlyS02 in Y. lipolytica, the alyS02 gene without signal sequence and stop codon was optimized through elimination of the rare codons used in that yeast and the negative cis-acting elements such as mRNA destabilizing motifs, RNase splicing sites and repetitive element (Figure S1). Then the 
optimized gene with a C-terminal $6 \times$ His-tag and N-terminal XPR2 signal peptide was synthesized by Genscript Biotech Co., Ltd. (Nanjing, China). In addition, two restriction sites (BamH I and Sfi I) were added at the ends of the gene. After the synthesized DNA was digested by BamH I and Sfi I, the purified fragment was ligated into the corresponding sites of the vector pINA1312 with an uracil synthesis gene (URA3) to create the final recombinant plasmid pINA1312-alyS02 (Figure S2) [81].

The pINA1312-alyS02 fragment linearized by Not I was transformed into Y. lipolytica URA ${ }^{-}$strain by LiAc method [83]. After $84 \mathrm{~h}$ incubation in GPPB medium at $30^{\circ} \mathrm{C}$, positive transformants were tested for alginate lyase activities. Finally, the recombinant strain $Y 32$ showed the highest extracellular activity. The recombinant strain Y32 was fermented in the GPPB medium for $72 \mathrm{~h}$. After centrifugation at $4{ }^{\circ} \mathrm{C}$ and $10,000 \times g$ for $5 \mathrm{~min}$, the culture supernatant was collected. BCA protein assay kit (Solarbio, Beijing, China) was used to determine the total protein concentration and the alginate lyase activity was detected as described below. The crude enzyme solution was concentrated by ultrafiltration with a centrifugal filter $3 \mathrm{~K}$ device (3000 nominal molecular mass limit) (Millipore, Burlington, MA, USA) and then was loaded on Ni-Sepharose column (GE Healthcare, Uppsala, Sweden) equilibrated with $300 \mathrm{mM}$ $\mathrm{NaCl}$ and $50 \mathrm{mM}$ phosphate buffer (pH 7.0). Then, the column was washed with the same buffer containing $20 \mathrm{mM}$ imidazole, and the $6 \times$ His-tagged alginate lyase was eluted with the same buffer containing a linear gradient of imidazole ( $50-500 \mathrm{mM})$. The active fractions were pooled, concentrated, and desalted, meanwhile, the buffer was replaced by $50 \mathrm{mM}$ Tris- $\mathrm{HCl}(\mathrm{pH}$ 7.0) with a Millipore centrifugal filter $3 \mathrm{~K}$ device for further enzyme characterization. The $\mathrm{Mw}$ of recombinant AlyS02 was determined by $12 \%$ sodium dodecyl sulfate-polyacrylamide gel electrophoresis (SDS-PAGE) system (Bio-Rad, Hercules, CA, USA) and the loading amount of recombinant AlyS02 was $10 \mu \mathrm{L}$. The protein marker was purchased from Solarbio Life Sciences (Beijing, China).

\subsection{Enzymatic Activity Assay of the Alginate Lyase}

To determine the activity of recombinant enzyme, $100 \mu \mathrm{L}$ of appropriately diluted AlyS02 was mixed with $900 \mu \mathrm{L}$ of substrate solution ( $1 \%(w / v)$ sodium alginate, $20 \mathrm{mM}$ Tris- $\mathrm{HCl}$ buffer, $\mathrm{pH}$ 7.6), and incubated for $10 \mathrm{~min}$ at $30^{\circ} \mathrm{C}$. The solution was heated in boiling water for $10 \mathrm{~min}$ to terminate the reaction. Then, $1 \mathrm{~mL}$ of 3,5-dinitrosalicylate (DNS) solution was added to the solution, and the mixture was reacted in a boiling water bath for $10 \mathrm{~min}$. Finally, the absorbance was measured at $540 \mathrm{~nm}$. One unit of alginate lyase activity was defined as the amount of enzyme required to release $1 \mu \mathrm{mol}$ of reducing saccharides (glucose equivalent) per min.

\subsection{Effects of Temperature and $p H$ on Recombinant AlySO2 Activity and Stability}

To study the effect of temperature on the enzyme activity, the activities of AlyS02 at different temperatures $\left(10-50^{\circ} \mathrm{C}\right)$ were measured, calculating the relative enzyme activity by setting the activity at the optimum temperature as $100 \%$. In addition, to evaluate the influence of temperature on AlyS02 stability, the enzyme was incubated for $2 \mathrm{~h}$ at different temperatures $\left(10-50{ }^{\circ} \mathrm{C}\right)$; at this time, residual enzyme activities were measured and calculated by using the initial activity as $100 \%$.

Meanwhile, the effects of $\mathrm{pH}$ (3.0-10.6) on the purified enzyme were investigated. Alginate lyase activities in different buffers, including $20 \mathrm{mM}$ citric acid- $\mathrm{NaH}_{2} \mathrm{PO}_{4}$ (pH 3.0-7.0), $\mathrm{NaH}_{2} \mathrm{PO}_{4}-\mathrm{Na}_{2} \mathrm{HPO}_{4}$ ( $\mathrm{pH}$ 6.4-8.0), Tris- $\mathrm{HCl}(\mathrm{pH} 7.0-9.0)$ and glycine- $\mathrm{NaOH}$ ( $\mathrm{pH} 8.6-10.6)$, were measured to assess the influence of $\mathrm{pH}$ on AlyS02 activity, calculating the relative enzyme activity by taking the activity at optimal $\mathrm{pH}$ as $100 \%$. In addition, to test the effect of $\mathrm{pH}$ on the stability of AlyS02, the enzyme was incubated at $4{ }^{\circ} \mathrm{C}$ for $24 \mathrm{~h}$ in different buffers above ( $\mathrm{pH}$ 3.0-10.6); here, the residual enzyme activities were measured and the maximum residual activity was considered as $100 \%$.

\subsection{Effects of $\mathrm{NaCl}$ and Metal Ions on the Activity of Recombinant AlySO2}

Enzyme reactions were performed in the presence of different concentrations of $\mathrm{NaCl}(100-900 \mathrm{mM})$ to evaluate the effect of $\mathrm{NaCl}$ on the activity of AlyS02. The enzyme activity in the absence of $\mathrm{NaCl}$ was used as control. To determine the influences of metal ions and chemical compounds on the enzyme 
activity, the residual enzyme activities of AlyS02 were analyzed after incubating for $24 \mathrm{~h}$ at $4{ }^{\circ} \mathrm{C}$ with the addition of different metal ions, EDTA and SDS at the concentration of $1 \mathrm{mM}$. The reaction mixture without any chemical compound and metal ion was used as control.

\subsection{Substrate Specificity of Recombinant AlySO2}

In this study, $1 \%(w / v)$ substrate solutions $(20 \mathrm{mM}$ Tris- $\mathrm{HCl}, \mathrm{pH} 7.6)$ with three kinds of polymers (polyG, polyM and sodium alginate) were used to measure the enzyme activities by the DNS method described above to assess the preferred substrate of recombinant AlyS02.

\subsection{Degradation Products Analysis of Recombinant AlySO2}

In order to clarify the mode of action of AlyS02 against sodium alginate, $0.5 \%(w / v)$ sodium alginate was used as the substrate, and completely degraded with excess enzyme (5 U per mg of substrate) at $30{ }^{\circ} \mathrm{C}$. The reaction mixture was continuously stirred and the degradation products were detected at regular time intervals. Then, the mixture solution was boiled for 10 min after incubation, and centrifuged at $12,000 \times g$ for $15 \mathrm{~min}$ to remove the unsolved materials. For removing proteins and other undegraded macromolecules, the supernatant was loaded on a centrifugal filter $3 \mathrm{~K}$ device (Millipore, Burlington, MA, USA). Then the filtrate was collected for detection.

First, the products were analyzed with a solvent system (1-butanol/acetic acid/water 2:1:1, v/v/v) using a TLC plate (TLC silica gel 60 F254, Merck KGaA, Darmstadt, Germany). After spraying with sulfuric acid/ethanol reagent $(1: 4, v / v)$, the TLC plate was heated at $80{ }^{\circ} \mathrm{C}$ for 30 min to visualize the spots. The mixture of disaccharide and trisaccharide was applied as a marker, and the total uronic acid concentration was $0.2 \%(w / v)$.

Next, a Superdex ${ }^{\mathrm{TM}}$ peptide 10/300 gel filtration column (GE Healthcare, Boston, MA, USA) was used for gel filtration chromatography analysis, and the complete degradation products were monitored at a wavelength of $235 \mathrm{~nm}$ by the ultraviolet detection system. The mobile phase was $0.2 \mathrm{M}$ $\mathrm{NH}_{4} \mathrm{HCO}_{3}$ at a flow rate of $0.6 \mathrm{~mL} / \mathrm{min}$ on an HPLC platform (LC-20A, Shimadzu, Japan). To further determine the composition of the end product, the filtrate was collected and mixed with methanol (1:1, $v / v$ ) and then quantitatively injected into an ESI-MS instrument (Bruker Esquire HCT, Billerica, MA, USA). The DPs of the enzymolysis products were profiled in negative-ion mode under the following conditions: calibration dynamics, 2; cone voltage, $20.00 \mathrm{~V}$; capillary voltage, $4.00 \mathrm{kV}$; desolvation temperature, $350{ }^{\circ} \mathrm{C}$; source temperature, $150{ }^{\circ} \mathrm{C}$; desolvation gas flow, $500 \mathrm{~L} / \mathrm{h}$; and cone gas flow rate, $50 \mathrm{~L} / \mathrm{h}$; scan range, $100-1500 \mathrm{~m} / \mathrm{z}$.

\section{Conclusions}

In this work, a novel PL7 family alginate lyase AlyS02 derived from marine bacterium Flavobacterium sp. S02 was expressed, purified and characterized. The optimal temperature and $\mathrm{pH}$ of this enzyme were $30^{\circ} \mathrm{C}$ and 7.6, respectively. AlyS02 was a cold-adapted enzyme with favorable stability. Moreover, AlyS02 exhibited bifunctional activity to release disaccharides and trisaccharides from alginate. These remarkable properties imply that AlyS02 would be a superior candidate for industrial applications.

Supplementary Materials: The following are available online at http://www.mdpi.com/1660-3397/18/8/388/s1. Figure S1: Comparison between the original and the codon-optimized alyS02 gene sequences without signal sequence and stop codon. The mutation sites introduced by codon optimization were highlighted in red, and the deduced amino acid sequence encoded by both the genes was shown below. Figure S2: Recombinant plasmid pINA1312-alyS02 for expression of alginate lyase AlyS02.

Author Contributions: H.-X.Z. conducted the experiments, and wrote this manuscript; S.-S.X. performed data processing and help to write this manuscript; X.-J.Y. analyzed the data; F.-L.W. and Y.L. supervised the research work and revised the manuscript. All authors have read and agreed to the published version of the manuscript.

Funding: This research was funded by Shandong Provincial Natural Science Foundation, China, grant number ZR2017BC029, and funded by China Postdoctoral Science Foundation, grant number 2016M602212. 
Conflicts of Interest: The authors declare no conflict of interest.

\section{References}

1. Wargacki, A.J.; Leonard, E.; Win, M.N.; Regitsky, D.D.; Santos, C.N.S.; Kim, P.B.; Cooper, S.R.; Raisner, R.M.; Herman, A.; Sivitz, A.B.; et al. An engineered Microbial platform for direct biofuel production from Brown Macroalgae. Science 2012, 335, 308-313. [CrossRef] [PubMed]

2. Ścieszka, S.; Klewicka, E. Algae in Food: A General Review. Crit. Rev. Food Sci. Nutr. 2019, 59, 3538-3547. [CrossRef] [PubMed]

3. Cardoso, S.M.; Pereira, O.R.; Seca, A.M.L.; Pinto, D.C.G.A.; Silva, A.M.S. Seaweeds as preventive agents for cardiovascular diseases: From nutrients to functional foods. Mar. Drugs. 2015, 13, 6838-6865. [CrossRef] [PubMed]

4. Tanna, B.; Mishra, A. Nutraceutical potential of seaweed polysaccharides: Structure, bioactivity, safety, and toxicity. Compr. Rev. Food Sci. Food 2019, 18, 817-831. [CrossRef]

5. Gacesa, P. Enzymic degradation of alginates. Int. J. Biochem. 1992, 24, 545-552. [CrossRef]

6. Aliste, A.J.; Vieira, F.F.; Mastro, N.L.D. Radiation effects on agar, alginates and carrageenan to be used as food additives. Radiat. Phys. Chem. 2000, 57, 305-308. [CrossRef]

7. Lee, K.Y.; Mooney, D.J. Alginate: Properties and biomedical applications. Prog. Polym. Sci. 2012, 37, $106-126$. [CrossRef]

8. Mathieu, S.; Touvreyloiodice, M.; Poulet, L.; Drouillard, S.; Vincentelli, R.; Henrissat, B.; Braek, G.S.; Helbert, W. Ancient acquisition of "alginate utilization loci" by human gut microbiota. Sci. Rep. 2018, 8, 8075. [CrossRef]

9. Laurienzo, P. Marine polysaccharides in pharmaceutical applications: An overview. Mar. Drugs 2010, 8, 2435-2465. [CrossRef]

10. Li, Y.; Wang, Z.; Xu, X.; Jin, L. A Ca-alginate particle co-immobilized with Phanerochaete chrysosporium cells and the combined cross-linked enzyme aggregates from Trametes versicolor. Bioresour. Technol. 2015, 198, 464-469. [CrossRef]

11. Zhu, B.; Chen, M.; Yin, H.; Du, Y.; Ning, L. Enzymatic hydrolysis of alginate to produce oligosaccharides by a new purified endo-type alginate lyase. Mar. Drugs 2016, 14, 108. [CrossRef] [PubMed]

12. Li, S.; Wang, L.; Liu, B.; He, N. Unsaturated alginate oligosaccharides attenuated obesity-related metabolic abnormalities by modulating gut microbiota in high-fat-diet mice. Food Funct. 2020, 11, 4773-4784. [CrossRef] [PubMed]

13. Hu, X.; Jiang, X.; Hwang, H.; Liu, S.; Guan, H. Antitumour activities of alginate-derived oligosaccharides and their sulphated substitution derivatives. Eur. J. Phycol. 2004, 39, 67-71. [CrossRef]

14. Yamamoto, Y.; Kurachi, M.; Yamaguchi, K.; Oda. T. Induction of multiple cytokine secretion from RAW264.7 Cells by alginate oligosaccharides. Biosci. Biotechnol. Biochem. 2007, 71, 238-241. [CrossRef] [PubMed]

15. Liu, H.; Geng, M.; Xin, X.; Li, F.; Zhang, Z.; Li, J.; Ding, J. Multiple and multivalent interactions of novel anti-AIDS drug candidates, sulfated polymannuronate (SPMG)-derived oligosaccharides, with gp120 and their anti-HIV activities. Glycobiology 2004, 15. [CrossRef]

16. Cherry, P.; Yadav, S.; Strain, C.R.; Allsopp, P.J.; Stanton, C. Prebiotics from seaweeds: An ocean of opportunity? Mar. Drugs 2019, 17, 327. [CrossRef]

17. Iwamoto, Y.; Xu, X.; Tamura, T.; Oda, T.; Muramatsu, T. Enzymatically depolymerized alginate oligomers that cause cytotoxic cytokine production in human mononuclear cells. Biosci. Biotechnol. Biochem. 2003, 67, 258-263. [CrossRef]

18. Falkeborg, M.; Cheong, L.; Gianfico, C.; Sztukiel, K.M.; Kristensen, K.; Glasius, M.; Xu, X.; Guo, Z. Alginate oligosaccharides: Enzymatic preparation and antioxidant property evaluation. Food Chem. 2014, 164, 185-194. [CrossRef]

19. Zhu, Y.; Wu, L.; Chen, Y.; Ni, H.; Xiao, A.; Cai, H. Characterization of an extracellular biofunctional alginate lyase from marine Microbulbifer sp. ALW1 and antioxidant activity of enzymatic hydrolysates. Microbiol. Res. 2016, 182, 49-58. [CrossRef]

20. Vera, J.; Castro, J.; Gonzalez, A.; Moenne, A. Seaweed polysaccharides and derived oligosaccharides stimulate defense responses and protection against pathogens in plants. Mar. Drugs 2011, 9, 2514-2525. [CrossRef] 
21. Zhang, Y.; Yin, H.; Zhao, X.; Wang, W.; Du, Y.; He, A.; Sun, K. The promoting effects of alginate oligosaccharides on root development in Oryza sativa L. mediated by auxin signaling. Carbohydr. Polym. 2014, 113, 446-454. [CrossRef] [PubMed]

22. Hu, X.; Jiang, X.; Hwang, H.; Liu, S.; Guan, H. Promotive effects of alginate-derived oligosaccharide on maize seed germination. J. Appl. Phycol. 2004, 16, 73-76. [CrossRef]

23. Wong, T.Y.; Preston, L.A.; Schiller, N.L. Alginate lyase: Review of major sources and enzyme characteristics, structure-function analysis, biological roles, and applications. Annu. Rev. Microbiol. 2000, 54, 289. [CrossRef] [PubMed]

24. Kim, H.S.; Lee, C.G.; Lee, E.Y. Alginate lyase: Structure, property, and application. Biotechnol. Bioprocess Eng. 2011, 16, 843-851. [CrossRef]

25. Zhu, B.; Tan, H.; Qin, Y.; Xu, Q.; Du, Y.; Yin, H. Characterization of a new endo-type alginate lyase from Vibrio sp. W13. Int. J. Biol. Macromol. 2015, 75, 330-337. [CrossRef]

26. Inoue, A.; Takadono, K.; Nishiyama, R.; Tajima, K.; Kobayashi, T.; Ojima, T. Characterization of an alginate lyase, FlAlyA, from Flavobacterium sp. strain UMI-01 and its expression in Escherichia coli. Mar. Drugs 2014, 12, 4693-4712. [CrossRef]

27. Yagi, H.; Isobe, N.; Itabashi, N.; Fujise, A.; Ohshiro, T. Characterization of a long-lived alginate lyase derived from Shewanella species YH1. Mar. Drugs 2018, 16, 4. [CrossRef]

28. Zhang, Z.; Tang, L.; Bao, M.; Liu, Z.; Yu, W.; Han, F. Functional characterization of carbohydrate-binding modules in a new alginate lyase, TsAly7B, from Thalassomonas sp. LD5. Mar. Drugs 2019, 18, 25. [CrossRef]

29. Li, S.; Wang, L.; Hao, J.; Xing, M.; Sun, J.; Sun, M. Purification and characterization of a new alginate lyase from marine bacterium Vibrio sp. SY08. Mar. Drugs 2017, 15, 1. [CrossRef]

30. Park, H.H.; Kam, N.; Lee, E.Y.; Kim, H.S. Cloning and characterization of a novel oligoalginate Lyase from a newly isolated bacterium Sphingomonas sp. MJ-3. Mar. Biotechnol. 2012, 14, 189-202. [CrossRef]

31. Jagtap, S.S.; Hehemann, J.H.; Polz, M.F.; Lee, J.K.; Zhao, H. Comparative biochemical characterization of three exolytic oligoalginate lyases from Vibrio splendidus reveals complementary substrate scope, temperature, and $\mathrm{pH}$ adaptations. Appl. Environ. Microbiol. 2014, 80, 4207-4214. [CrossRef] [PubMed]

32. Huang, L.; Zhou, J.; Li, X.; Peng, Q.; Lu, H.; Du, Y. Characterization of a new alginate lyase from newly isolated Flavobacterium sp. S20. J. Ind. Microbiol. Biotechnol. 2013, 40, 113-122. [CrossRef] [PubMed]

33. Kim, D.E.; Lee, E.Y.; Kim, H.S. Cloning and characterization of alginate lyase from a marine bacterium Streptomyces sp. ALG-5. Mar. Biotechnol. 2009, 11, 10-16. [CrossRef] [PubMed]

34. Zhu, B.-W.; Tan, H.-D.; Qin, Y.-Q.; Du, Y.-G.; Yin, H. Characterization of a new endo-type polyM-specific alginate lyase from Pseudomonas sp. Biotechnol. Lett. 2015, 37, 409-415. [CrossRef]

35. Chen, P.; Zhu, Y.; Men, Y.; Zeng, Y.; Sun, Y. Purification and characterization of a novel alginate lyase from the marine bacterium Bacillus sp. Alg07. Mar. Drugs 2018, 16, 86. [CrossRef]

36. Li, J.-W.; Dong, S.; Song, J.; Li, C.-B.; Chen, X.-L.; Xie, B.B.; Zhang, Y.Z. Purification and characterization of a bifunctional alginate lyase from Pseudoalteromonas sp. SM0524. Mar. Drugs 2011, 9, 109-123. [CrossRef]

37. Dou, W.; Wei, D.; Li, H.; Li, H.; Rahman, M.M.; Shi, J.; Xu, Z.; Ma, Y. Purification and characterisation of a bifunctional alginate lyase from novel Isoptericola halotolerans CGMCC 5336. Carbohydr. Polym. 2013, 98, 1476-1482. [CrossRef]

38. Yan, J.; Chen, P.; Zeng, Y.; Men, Y.; Sun, Y. The Characterization and modification of a novel bifunctional and robust alginate lyase derived from Marinimicrobium sp. H1. Mar. Drugs 2019, 17, 545. [CrossRef]

39. Yamasaki, M.; Moriwaki, S.; Miyake, O.; Hashimoto, W.; Murata, K.; Mikami, B. Structure and function of a hypothetical Pseudomonas aeruginosa protein PA1167 classified into family PL-7 a novel alginate lyase with a $\beta$-sandwich fold. Int. J. Biol. Chem. 2004, 279, 31863-31872. [CrossRef]

40. Belik, A.A.; Silchenko, A.S.; Kusaykin, M.I.; Zvyagintseva, T.N.; Ermakova, S.P. Alginate lyases: Substrates, structure, properties, and prospects of application. Russ. J. Bioorg. Chem. 2018, 44, 386-396. [CrossRef]

41. Huang, G.; Wang, Q.; Lu, M.; Chao, X.; Fei, L.; Zhang, R.; Liao, W.; Huang, S. AlgM4: A new salt-activated alginate lyase of the PL7 family with endolytic activity. Mar. Drugs 2018, 16, 120. [CrossRef] [PubMed]

42. Zhu, B.; Ni, F.; Sun, Y.; Ning, L.; Yao, Z. Elucidation of degrading pattern and substrate recognition of a novel bifunctional alginate lyase from Flammeovirga sp. NJ-04 and its use for preparation alginate oligosaccharides. Biotechnol. Biofuels 2019, 12, 13. [CrossRef] [PubMed] 
43. Li, S.; Wang, Z.; Wang, L.; Peng, J.; Wang, Y.; Han, Y.; Zhao, S. Combined enzymatic hydrolysis and selective fermentation for green production of alginate oligosaccharides from Laminaria japonica. Bioresour. Technol. 2019, 281, 84-89. [CrossRef] [PubMed]

44. Aarstad, O.A.; Tondervik, A.; Sletta, H.; Skjakbraek, G. Alginate sequencing: An analysis of block distribution in alginates using specific alginate degrading enzymes. Biomacromolecules 2012, 13, 106-116. [CrossRef] [PubMed]

45. Inoue, A.; Mashino, C.; Kodama, T.; Ojima, T. Protoplast preparation from Laminaria japonica with recombinant alginate lyase and cellulase. Mar. Biotechnol. 2011, 13, 256-263. [CrossRef]

46. Lamppa, J.W.; Griswold, K.E. Alginate lyase exhibits catalysis-independent biofilm dispersion and antibiotic synergy. Antimicrob. Agents Chemother. 2013, 57, 137-145. [CrossRef]

47. Islan, G.A.; Martinez, Y.N.; Illanes, A.; Castro, G.R. Development of novel alginate lyase cross-linked aggregates for the oral treatment of cystic fibrosis. RSC Adv. 2014, 4, 11758. [CrossRef]

48. Tang, J.C.; Taniguchi, H.; Chu, H.; Zhou, Q.; Nagata, S. Isolation and characterization of alginate degrading bacteria for disposal of seaweed wastes. Lett. Appl. Microbiol. 2008, 48, 38-43. [CrossRef]

49. Singh, R.P.; Gupta, V.; Kumari, P.; Kumar, M.; Reddy, C.R.K.; Prasad, K.; Jha, B. Purification and partial characterization of an extracellular alginate lyase from Aspergillus oryzae isolated from brown seaweed. J. Appl. Phycol. 2011, 23, 755-762. [CrossRef]

50. Hashimoto, W.; Miyake, O.; Ochiai, A.; Murata, K. Molecular identification of Sphingomonas sp. A1 alginate lyase (A1-IV') as a member of novel polysaccharide lyase family 15 and implications in alginate lyase evolution. J. Biosci. Bioeng. 2005, 99, 48-54. [CrossRef]

51. Zhu, B.; Ni, F.; Ning, L.; Sun, Y.; Yao, Z. Cloning and characterization of a new pH-stable alginate lyase with high salt tolerance from marine Vibrio sp. NJ-04. Int. J. Biol. Macromol. 2018, 115, 1063-1070. [CrossRef] [PubMed]

52. Suzuki, H.; Suzuki, K.I.; Inoue, A.; Ojima, T. A novel oligoalginate lyase from abalone, Haliotis discus hannai, that releases disaccharide from alginate polymer in an exolytic manner. Carbohydr. Res. 2006, 341, 1809-1819. [CrossRef]

53. Shiraiwa, Y.; Abe, K.; Sasaki, S.F.; Ikawa, T.; Nisizawa, K. Alginate lyase activities in the extracts from several brown algae. Bot. Mar. 2009, 18, 97-104. [CrossRef]

54. Ogura, K.; Yamasaki, M.; Yamada, T.; Mikami, B.; Hashimoto, W.; Murata, K. Crystal structure of Family 14 polysaccharide lyase with pH-dependent modes of action. Int. J. Biol. Chem. 2009, 284, 35572-35579. [CrossRef] [PubMed]

55. Zhu, B.; Yin, H. Alginate lyase: Review of major sources and classification, properties, structure-function analysis and applications. Bioengineered 2015, 6, 125-131. [CrossRef] [PubMed]

56. Sim, S.J.; Baik, K.S.; Park, S.C.; Choe, H.N.; Seong, C.N.; Shin, T.S.; Woo, H.C.; Cho, J.Y.; Kim, D. Characterization of alginate lyase gene using a metagenomic library constructed from the gut microflora of abalone. J. Ind. Microbiol. Biotechnol. 2012, 39, 585-593. [CrossRef] [PubMed]

57. Zeng, J.; An, D.; Jiao, C.; Xiao, Q.; Weng, H.; Yang, Q.; Xiao, A. Cloning, expression, and characterization of a new $\mathrm{pH}$ - and heat-stable alginate lyase from Pseudoalteromonas carrageenovora ASY5. J. Food Biochem. 2019, 43, e12886. [CrossRef]

58. Inoue, A.; Anraku, M.; Nakagawa, S.; Ojima, T. Discovery of a novel alginate lyase from Nitratiruptor sp. SB155-2 Thriving at deep-sea hydrothermal vents and identification of the residues responsible for its heat stability. Int. J. Biol. Chem. 2016, 291, 15551-15563. [CrossRef]

59. Chen, X.-L.; Dong, S.; Xu, F.; Dong, F.; Li, P.-Y.; Zhang, X.Y.; Zhou, B.C.; Zhang, Y.Z.; Xie, B.B. Characterization of a new cold-adapted and salt-activated polysaccharide lyase family 7 alginate lyase from Pseudoalteromonas sp. SM0524. Front. Microbiol. 2016, 7, 1120. [CrossRef]

60. Gao, S.; Zhang, Z.; Li, S.; Su, H.; Tang, L.; Tan, Y.; Yu, W.; Han, F. Characterization of a new endo-type polysaccharide lyase (PL) family 6 alginate lyase with cold-adapted and metal ions-resisted property. Int. J. Biol. Macromol. 2018, 120, 729-735. [CrossRef]

61. Wang, Y.; Chen, X.; Bi, X.; Ren, Y.; Han, Q.; Zhou, Y.; Han, Y.; Li, S. Characterization of an alkaline alginate lyase with pH-stable and thermo-tolerance property. Mar. Drugs 2019, 17, 308. [CrossRef] [PubMed] 
62. Kobayashi, T.; Uchimura, K.; Miyazaki, M.; Nogi, Y.; Horikoshi, K. A new high-alkaline alginate lyase from a deep-sea bacterium Agarivorans sp. Extremophiles 2009, 13, 121-129. [CrossRef] [PubMed]

63. Hu, X.; Jiang, X.; Hwang, H.-M. Purification and characterization of an alginate lyase from marine bacterium Vibrio sp. mutant strain 510-64. Curr. Microbiol. 2006, 53, 135-140. [CrossRef] [PubMed]

64. Zhang, Y.; Shao, Y.; Jiao, C.; Yang, Q.; Weng, H.; Xiao, A.F. Characterization and application of an alginate lyase, Aly1281 from marine bacterium Pseudoalteromonas carrageenovora ASY5. Mar. Drugs 2020, $18,95$. [CrossRef]

65. Yamasaki, M.; Ogura, K.; Hashimoto, W.; Mikami, B.; Murata, K. A structural basis for depolymerization of alginate by polysaccharide lyase family-7. J. Mol. Biol. 2005, 352, 11-21. [CrossRef]

66. Thomas, F.; Lundqvist, L.C.E.; Jam, M.; Jeudy, A.; Barbeyron, T.; Sandstrom, C.; Michel, G.; Czjzek, M. Comparative characterization of two marine alginate lyases from Zobellia galactanivorans reveals distinct modes of action and exquisite adaptation to their natural substrate. Int. J. Biol. Chem. 2013, 288, 23021-23037. [CrossRef]

67. Li, H.; Wang, S.; Zhang, Y.; Chen, L. High-level expression of a thermally stable alginate lyase using pichia pastoris, characterization and application in producing brown alginate oligosaccharide. Mar. Drugs 2018, 16, 158. [CrossRef]

68. Madzak, C. Yarrowia lipolytica: Recent achievements in heterologous protein expression and pathway engineering. Appl. Microbiol. Biotechnol. 2015, 99, 4559-4577. [CrossRef]

69. Iwamoto, Y.; Araki, R.; Iriyama, K.-I.; Oda, T.; Fukuda, H.; Hayashida, S.; Muramastu, T. Purification and characterization of bifunctional alginate lyase from Alteromonas sp. strain no. 272 and its action on saturated oligomeric substrates. Biosci. Biotechnol. Biochem. 2001, 65, 133-142. [CrossRef]

70. Han, M.; Wang, X.; Ding, H.; Jin, M.; Yu, L.; Wang, J.; Yu, X. The role of N-glycosylation sites in the activity, stability, and expression of the recombinant elastase expressed by Pichia pastoris. Enzyme. Microb. Technol. 2014, 54, 32-37. [CrossRef]

71. Zou, S.; Huang, S.; Kaleema, I.; Li, C. N-glycosylation enhances functional and structural stability of recombinant $\beta$-glucuronidase expressed in Pichia pastoris. J. Biotechnol. 2013, 164, 75-81. [CrossRef] [PubMed]

72. Kunjukunju, S.; Roy, A.; . Shekhar, S.; Kumta, P.N. Cross-linked enzyme aggregates of alginate lyase: A systematic engineered approach to controlled degradation of alginate hydrogel. Int. J. Biol. Macromol. 2018, 115, 176-184. [CrossRef] [PubMed]

73. Peng, C.; Wang, Q.; Lu, D.; Han, W.; Li, F. A novel bifunctional endolytic alginate lyase with variable alginate-degrading modes and versatile monosaccharide-producing properties. Front. Microbiol. 2018, 9, 167. [CrossRef] [PubMed]

74. Uchimura, K.; Miyazaki, M.; Nogi, Y.; Kobayashi, T.; Horikoshi, K. Cloning and sequencing of alginate lyase genes from deep-sea strains of Vibrio and Agarivorans and characterization of a new Vibrio enzyme. Mar. Biotechnol. 2010, 12, 526-533. [CrossRef] [PubMed]

75. Fu, X.T.; Lin, H.; Kim, S.M. Purification and characterization of a $\mathrm{Na}^{+} / \mathrm{K}^{+}$dependent alginate lyase from turban shell gut Vibrio sp. YKW-34. Enzyme Microb. Technol. 2007, 41, 828-834. [CrossRef]

76. Ochi, Y.; Takeuchi, T.; Murata, K.; Kawabata, Y.; Kusakabe, I. A simple method for preparation of poly-mannuronate using poly-guluronate lyase. Biosci. Biotechnol. Biochem. 1995, 59, 1560-1561. [CrossRef]

77. Miyake, O.; Ochiai, A.; Hashimoto, W.; Murata, K. Origin and diversity of alginate lyases of families PL-5 and -7 in Sphingomonas sp. strain A1. J. Bacteriol. 2004, 186, 2891-2896. [CrossRef]

78. Chen, J.; Hu, Y.; Zhang, L.; Wang, Y.; Wang, S.; Zhang, Y.; Guo, H.; Ji, D.; Wang, Y. Alginate oligosaccharide DP5 exhibits antitumor effects in osteosarcoma patients following surgery. Front. Pharmacol. 2017, 8, 623. [CrossRef]

79. Kawada, A.; Hiura, N.; Tajima, S.; Takahara, H. Alginate oligosaccharides stimulate VEGF-mediated growth and migration of human endothelial cells. Arch. Dermatol. Res. 1999, 291, 542-547. [CrossRef]

80. Iwasaki, K.; Matsubara, Y. Purification of alginate oligosaccharides with root growth-promoting activity toward lettuce. Biosci. Biotechnol. Biochem. 2000, 64, 1067-1070. [CrossRef] 
81. Zhang, P.; Wang, Z.P.; Sheng, J.; Zheng, Y.; Ji, X.F.; Zhou, H.X.; Liu, X.Y.; Chi, Z.M. High and efficient isomaltulose production using an engineered Yarrowia lipolytica strain. Bioresour. Technol. 2018, 265, 577-580. [CrossRef] [PubMed]

82. Tamura, K.; Stecher, G.; Peterson, D.; Filipski, A.; Kumar, S. MEGA6: Molecular evolutionary genetics analysis version 6.0. Mol. Biol. Evol. 2013, 30, 2725-2729. [CrossRef] [PubMed]

83. Gietz, R.D.; Schiestl, R.H. High-efficiency yeast transformation using the LiAc/SS carrier DNA/PEG method. Nat. Protoc. 2007, 2, 31-34. [CrossRef] [PubMed]

(C) 2020 by the authors. Licensee MDPI, Basel, Switzerland. This article is an open access article distributed under the terms and conditions of the Creative Commons Attribution (CC BY) license (http://creativecommons.org/licenses/by/4.0/). 